\title{
The analysis of operating conditions for valves actuated by camless coupled drive
}

\begin{abstract}
The operating conditions for the pair of inlet or exhaust valves in a single engine cylinder has been analyzed. The differences for the phase angle position of cams, due to manufacturing faults, vibration and wear, result in differences in valve lifts for such a pair. The use of a single camless drive for the pair of valves cannot eliminate such differences in the valve lifts. When individual drive for each valve is used, the differences can be greater. The aim of the analysis is to determine the needed stiffness of the element connecting the pair of valves with the drive and permissible differences for geometrical and material properties of an individual drive, allowing to obtain the differences for the valve lifts smaller than those for the camshaft case. The analysis has been made using the elaborated FEM model, for two configurations of the camless drive. The paper also presents the dynamic parameters of the valves - drive assembly, stresses in such assembly and recommendations for stiffness of the element connecting the pair of valves with the drive.
\end{abstract}

Key words: combustion engine, valve timing, camless drive, operating conditions, finite element method

\section{Analiza warunków pracy zaworów napędzanych przez bezkrzywkowy zblokowany napęd}

\begin{abstract}
Analizowano pracę pary zaworów ssacych lub wydechowych $w$ pojedynczym cylindrze silnika. Zmiany położenia krzywek, wynikające z błędów wykonania, drgań i zużycia, skutkuja różnicami w przebiegach wzniosów takiej pary zaworów. Zastosowanie pojedynczego bezkrzywkowego napędu dla takiej pary nie eliminuje różnic w przebiegach wzniosów tych zaworów. Przy indywidualnym napędzie każdego zaworu różnice te mogą być większe. Celem analizy jest ustalenie wymaganej sztywności elementu tączącego parę zaworów z bezkrzywkowym napędem oraz dopuszczalnych różnic parametrów geometrycznych i materiałowych indywidualnych napędów pozwalajacych uzyskiwać różnice $w$ przebiegu wzniosów tych zaworów, nie większych niż dla napędu krzywkowego. Analizę wykonano w modelu MES dla dwóch konfiguracji bezkrzywkowego napędu. Zamieszczono wykresy parametrów dynamicznych układu zawory-napęd bezkrzywkowy, naprężenia w uktadzie i zalecenia co do sztywności elementu taczacego zawory z napędem.
\end{abstract}

Słowa kluczowe: silnik spalinowy, rozrząd zaworów, napęd bezkrzywkowy, warunki pracy, metoda elementów skończonych

\section{Introduction}

In contemporary engines there is a trend to use four valves per each cylinder, including two inlet valves and two exhaust valves. The valves are mostly driven by cam drives. Researchers are conducting studies on the replacement of the cam drives by camless ones. The drive may be realized through electrohydraulic, electromechanic or magnetoelectric assemblies. In the case of an electromechanic drive, e.g. in the studied engines manufactured by Valeo [1] (Fig. 1), they applied a system, in which each driven inlet valve was associated with a single drive. It is also possible to use a camshaft, in which each a single blocked drive serves for driving of two inlet or exhausts valves.

In such a case both valves are connected by an element with appropriate stiffness and a camless drive. In this paper the magnetoelectric drive is analyzed with its two examples of configurations making it possible to realize the blocked drive for two inlet or exhaust valves. Moreover, the integrated drive was analyzed with its configuration making it possible to realize common driving of two inlet or exhaust valves in a single engine cylinder. In the integrated drive single movable coils are associated with separate valves and placed in a common electromagnetic circuit. The important problem, which occurs while using the blocked or integrated drive of camshaft valves, is the synchronization of motion

\section{Wprowadzenie}

Obecnie w silnikach spalinowych występuje tendencja do stosowania dla każdego cylindra po cztery zawory: dwa ssące i dwa wydechowe. Przykładem mogą tu być silniki samochodów marek: Audi, Daewoo Lanos. W większości zawory takie są napędzane krzywkowo. Obecnie trwają prace studialne nad zastąpieniem krzywkowego napędu zaworów rozrządu przez napęd bezkrzywkowy. Napęd taki może być realizowany elektrohydraulicznie, elektropneumatycznie, elektromechanicznie lub magnetoelektrycznie. W przypadku realizacji elektromechanicznego napędu, jak na przykład w studialnych silnikach firmy Valeo [1] (rys. 1), zastosowano układ, w którym każdy napędzany zawór ssący skojarzony był z pojedynczym napędem. Możliwa jest też realizacja rozrządu, w którym pojedynczy zblokowany napęd służy do napędzania dwóch zaworów ssących lub wydechowych.

Oba zawory są wówczas połączone przez element, o odpowiedniej sztywności, z bezkrzywkowym napędem. W niniejszym artykule analizowano napęd magnetoelektryczny, którego dwie przykładowe konfiguracje umożliwiają realizację zblokowanego napędu, dla dwóch zaworów ssących lub wydechowych. Ponadto analizie poddano napęd zintegrowany, o konfiguracji pozwalającej na realizację wspólnego napędzania dwóch zaworów ssących lub wyde- 
of both valves, which, ideally, should be realized simultaneously and recurrently for the same conditions of the engine load and its rotating speed. In fact, dynamic parameters of motions of valves connected with the blocked or integrated drive are not identical. They differ in instantaneous amplitude and are often shifted in phase. The reasons for this are, most of all, vibrations of the element connecting both valves and the camless drive. In the case of use of the integrated drive, simultaneous powering of individual coils associated with separate valves may be impeded due to voltage drops occurring in the drive electric system. Additionally, in all cases, geometrical and material parameters of elements of the valves-drive assembly play a significant role in the occurrence of differences in motions of the drive valves. The analyzed drives were compared to the cam drive, in which a single shaft drives two inlet or exhaust drives. The aim of the analysis was to establish the required stiffness of the element connecting a pair of valves with the camless drive as well as the admissible differences between geometrical and material parameters of individual drives making it possible to obtain differences in the course of the lifts of the valves being no higher than those for the cam drive. The analysis was performed with the use of FEM model for two configurations of the blocked drive and integrated drive.

\section{Dynamic parameters of the valves-drive assembly}

Figures 2 and 3 present diagrams of the analyzed two configurations of the blocked drive. The blocked drive consists of steel upper, central and lower pole shoes as well as a core, two NdFeB magnets, aluminium base, soft copper springs carrying the current to the movable coil as placed on the coil form and made of rezotex. [2]. The driven valves are, regardless of their configuration, connected by a joining element or they are directly connected with the coil form.

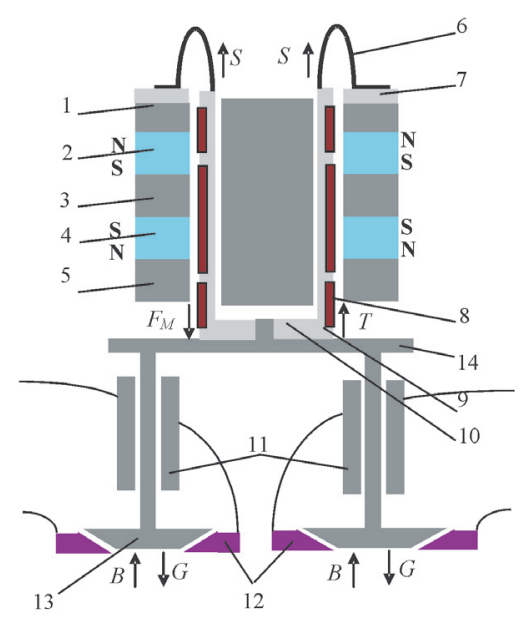

Fig. 2. The schematics of the blocked magnetoelectric valve driving, configuration 1; 1, 3, 5 - the pole shoe, 2, 4-magnet, 6 - base, 7 - spring, 8 - coil winds, 9 - coil form, 10 - core, 11 - valve guide, 12 - valve seat, 13 - valve, 14 - connecting element

Rys. 2. Schemat zblokowanego magnetoelektrycznego napędu zaworów rozrzadu, konfiguracja 1; 1, 3, 5-nabiegunnik, 2, 4-magnes staty,

6-podstawa, 7 - miękka sprężyna, 8-uzwojenie cewki, 9-karkas cewki, 10 -rdzeń, 11 - prowadnica, 12 -gniazdo, 13 -zawór, 14-tącznik

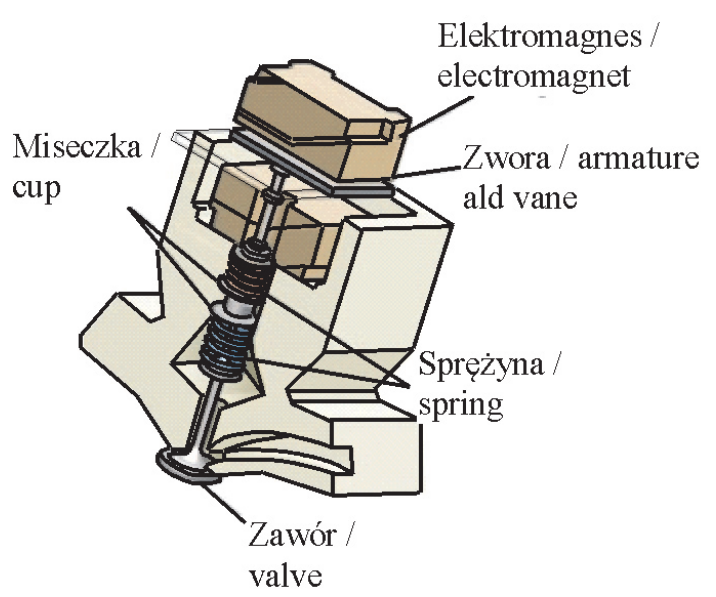

Fig. 1. The schematics of an electromechanic valve drive in the combustion engine, manufactured by Valeo, drawing based on [1]

Rys. 1. Schemat elektromechanicznego napędu zaworu rozrządu w silniku firmy Valeo, rysunek na podstawie [1]

chowych, w pojedynczym cylindrze silnika. W napędzie zintegrowanym poruszające się pojedyncze cewki, skojarzone z oddzielnymi zaworami, są umieszczone we wspólnym obwodzie magnetycznym. Ważnym problemem, który występuje podczas stosowania zblokowanego lub zintegrowanego napędu zaworów rozrządu jest synchronizacja ruchów obu zaworów, które w idealnym przypadku powinny odbywać się w sposób jednoczesny i powtarzalny, dla takich samych warunków obciążenia silnika i jego prędkości obrotowej. W rzeczywistości parametry dynamiczne ruchów zaworów połączonych ze zblokowanym lub zintegrowanym napędem nie są identyczne. Różnią się pod względem chwilowej amplitudy i są często przesunięte $\mathrm{w}$ fazie. Powodem tego są przede wszystkim drgania elementu łączącego oba zawory z napędem bezkrzywkowym. W sytuacji zastosowania zintegrowanego

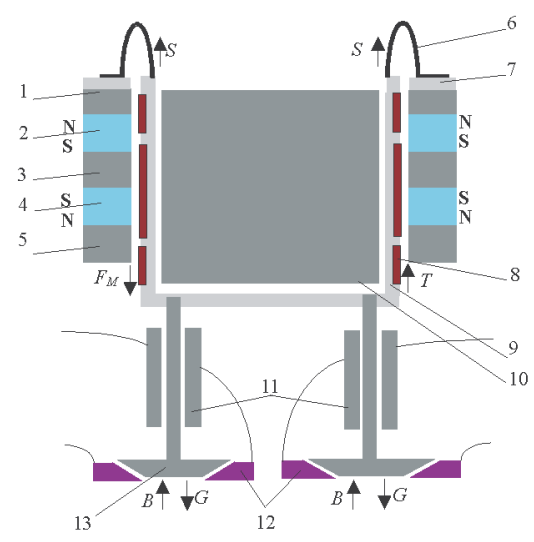

Fig. 3. The schematics of the blocked magnetoelectric valve driving, of configuration $2 ; 1,3,5$ - the pole shoe, 2, 4- sintered magnet, 6 - base,

7 - spring, 8 - coil winds, 9 - coil form, 10 - core, 11 - valve guide, 12 - valve seat, 13 - valve

Rys. 3. Schemat zblokowanego magnetoelektrycznego napędu zaworów rozrządu, konfiguracja 2; 1, 3, 5-nabiegunnik, 2, 4-magnes stały, 6-podstawa, 7 -miękka sprężyna, 8-uzwojenie cewki, 9-karkas cewki, 10-rdzeń, 11 - prowadnica, 12 - gniazdo zaworu, 13 -zawór 
Valve stems are mounted on bearings in guides, whereas valve heads cooperate with valve seats. Figure 4 presents a schematics of the integrated drive of camshaft valves. The integrated drive differs from the above-mentioned drives in its two movable coils, each of which serves to drive an individual valve. As already mentioned, the coils are located in the common magnetic circuit.

In both configurations of the blocked drive and in the case of the integrated drive, the drives-valve assembly is loaded by a similar arrangement of forces.

The drives-valve assembly is loaded by the following forces [3]:

- FM electromagnetic force

- P gas force

$-\mathrm{B}$ inertia force

- S spring force

- G assembly gravity force

- T damping force.

For the analysis of the spring force, the weight was disregarded. The damping force for the coil form made of rezorex is $50 \mathrm{~N}$, whereas for aluminum coil form it is $100 \mathrm{~N}$ due to generation of eddy currents during a motion of the coil in the magnetic field.

The inertia force was calculated on the basis of the following formula (1):

$$
\mathrm{B}=\mathrm{m} \cdot \mathrm{a}
$$

where:

$\mathrm{m}=176 \mathrm{~g}-$ weight of the coil-connecting element-valves assembly, blocked drive, configuration 1 , variant 1 , identical valve weights,

$\mathrm{m}=178.8 \mathrm{~g}$ - weight of the coil-connector-valves assembly, blocked drive, configuration 1, variant $1,5 \%$ difference in weights of valves and connecting element,

$\mathrm{m}=186 \mathrm{~g}$ - weight of the coil-connector-valves assembly, blocked drive, configuration 1 , variant 2 ,

$\mathrm{m}=183 \mathrm{~g}$ - weight of the coil-connector-valves assembly, blocked drive, configuration 1 , variant 3 ,

$\mathrm{m}=224 \mathrm{~g}-$ for the coil-valves assembly, blocked drive, configuration 2 ,

$\mathrm{m}=113 \mathrm{~g}$-weight of the drive coil-exhaust valve assembly, integrated drive, coil form made of aluminum alloy,

$\mathrm{m}=103 \mathrm{~g}$ - weight of the drive coil-exhaust valve assembly, integrated drive, coil form made of rezotex [2],

$\mathrm{m}=107 \mathrm{~g}-$ weight of the coil drive-inlet valve assembly, integrated drive, coil form made of aluminum alloy,

$\mathrm{m}=100 \mathrm{~g}$ - weight of the coil drive-inlet valve assembly, integrated drive, coil form made of rezotex [2].

Time $(\mathrm{t})$ of the assembly motion may be estimated depending on (2):

$$
\mathrm{t}=4 \cdot \sqrt{\frac{\mathrm{H}}{\mathrm{a}}}
$$

where: $\mathrm{H}=7 \mathrm{~mm}-$ maximum valve lift [3].

The gas force is calculated on the basis of the following formula (3):

$$
\mathrm{P}=\mathrm{p}_{\mathrm{g}} \cdot \mathrm{A}=\mathrm{p}_{\mathrm{g}} \cdot 0.25 \cdot \pi \cdot \mathrm{d}^{2}
$$

napędu jednoczesne zasilanie indywidualnych cewek skojarzonych z oddzielnymi zaworami może być utrudnione $\mathrm{z}$ powodu spadków napięć występujących w układzie elektrycznym napędu. Ponadto we wszystkich przypadkach istotną rolę w powstawaniu różnic w przebiegach ruchu napędzanych zaworów odgrywają parametry geometryczne i materiałowe elementów układu zawory-napęd. Analizowane napędy porównano z napędem krzywkowym, w którym pojedynczy wałek napędza popychacze dwóch zaworów ssących lub wydechowych. Analiza miała na celu ustalenie wymaganej sztywności elementu łączącego parę zaworów z bezkrzywkowym napędem oraz dopuszczalnych różnic parametrów geometrycznych i materiałowych indywidualnych napędów, pozwalających uzyskiwać różnice w przebiegu wzniosów tych zaworów, nie większych niż dla napędu krzywkowego. Analizę wykonano w modelu MES dla dwóch konfiguracji zblokowanego napędu oraz dla napędu zintegrowanego.

\section{Parametry dynamiczne układu napęd-zawór}

Schematy analizowanych dwóch konfiguracji napędu zblokowanego przedstawiono na rys. 2 i 3. Napęd taki składa się ze stalowych nabiegunników górnego, środkowego i dolnego oraz rdzenia, dwóch magnesów stałych $\mathrm{NdFeB}$, aluminiowej podstawy, miękkich miedzianych sprężyn, doprowadzających prąd do uzwojeń ruchomej cewki, osadzonych na karkasie, wykonanym z rezotexu [2]. Napędzane zawory, zależnie od konfiguracji, są połączone bądź elementem łączącym z karkasem cewki, bądź bezpośrednio z karkasem cewki.

Trzonki zaworów są ułożyskowane w prowadnicach, a grzybki zaworów współpracują z gniazdami zaworów. $\mathrm{Na}$ rysunku 4 przedstawiono schemat zintegrowanego napędu zaworów rozrządu. Zintegrowany napęd różni się od wyżej opisanych tym, że ma dwie ruchome cewki, z których każda przeznaczona jest do napędu pojedynczego zaworu. Cewki te są umieszczone, jak już wspomniano, we wspólnym obwodzie magnetycznym.

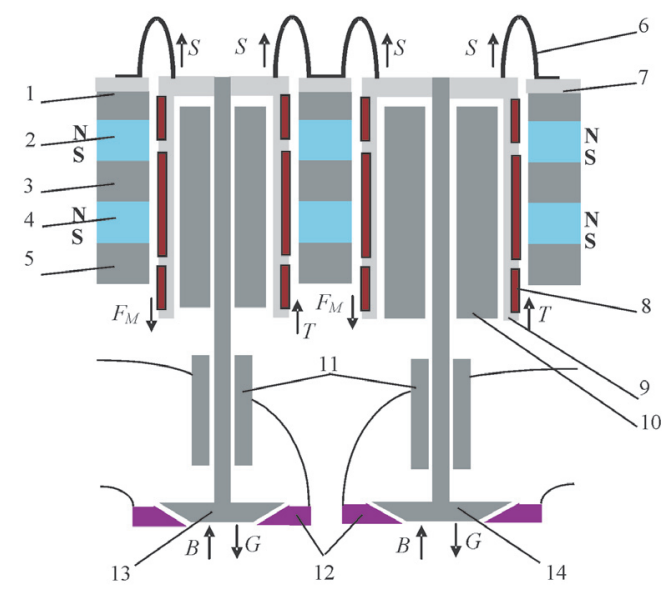

Fig. 4. The schematics of the integrated magnetoelectric valve driving of configuration $1 ; 1,3,5$ - the pole shoe, 2, 4- sintered magnet, 6 - base,

7 - spring, 8 - coil winds, 9 - coil form, 10 - core, 11 - valve guide, 12 - valve set, 13 - valve

Rys. 4. Schemat zintegrowanego napędu zaworów rozrządu:

1, 3, 5-nabiegunnik, 2, 4-magnes staty, 6-podstawa, 7-miękka sprężyna, 8-uzwojenie cewki, 9-karkas cewki, 10-rdzeń,

11 - prowadnica, 12 - gniazdo zaworu, 13 -zawór 
where: $\mathrm{d}=27 \mathrm{~mm}$ - average diameter of the valve head; the value of $27 \mathrm{~mm}$ is characteristic of diesel engines in passenger vehicles, $\mathrm{p}_{\mathrm{g}}=0.5 \mathrm{MPa}-$ gas pressure in the engine cylinder, the gas pressure loads the exhaust valve when opened.

The coil acceleration may be calculated on the basis of the following formula (4) [3]:

$$
\mathrm{a}=\frac{\mathrm{F}_{\mathrm{M}}-\mathrm{P}-\mathrm{T}}{\mathrm{m}}
$$

During simulation of the motion of the coil drive-valve assembly, acceleration of the coil drive-valve assembly for the camshaft operating outside the engine may be calculated on the basis of the following formula (5):

$$
\mathrm{a}=\frac{\mathrm{F}_{\mathrm{M}}-\mathrm{T}}{\mathrm{m}}
$$

The density of cylinder $\rho_{\mathrm{v}}$ material was calculated on the basis of the following formula (6):

$$
\rho_{\mathrm{v}}=\frac{4 \cdot \mathrm{m}_{\mathrm{v}}}{\pi \cdot \mathrm{d}_{\mathrm{v}}^{2} \cdot \mathrm{h}_{\mathrm{v}}}
$$

The material properties of elements included in the movable drive coil are presented in Table 1 .

\section{Determination of electrodynamic force gener- ated in the blocked drive}

Individual drives capable of generating various electromagnetic forces must be used for driving of two inlet and exhaust valves. The forces in the exhaust valve drive must be greater than the gas force due to a higher load of the valves. The schematics of the magnetoelectric drive for exhaust valves is presented in Fig. 5.

The schematics of magnetoelectric drive for inlet valves is presented in Fig. 6.

For driving of exhaust or inlet valves one may also use magnetoelectric drive with different configuration of the movable coil. The schematics of the above-mentioned drive is presented in Fig. 7.

One may also use integrated drive for driving of the inlet or exhaust valves. The drive schematics is presented in Fig. 8.

During the flow of current in the drive coil moving in the magnetic field originating from the sintered magnets-pole shoes-air gap, electrodynamic force directed along the coil axis is generated. The values of the electrodynamic force generated in the drive were determined by FEM method with the use of commercial software. In order to simplify the analysis, the axis symmetrical model was assumed. A flat eight-node element ending in PLANE53 was used with its degrees of freedom being the values of the component of vector magnetic potential $A_{z}$. The grid of elements was generated automatically by the program. The grid of finite elements and boundary conditions for exhaust valve drive are presented in Fig. 9, and for inlet valve drive in Fig. 10.
W obu konfiguracjach napędu zblokowanego, a także w przypadku napędu zintegrowanego układ napęd-zawory jest obciążony podobnym układem sił. Układ napęd-zawory jest obciążany następującymi siłami [3]:

- elektromagnetyczną FM

- gazową P

- bezwładności B

- sprężyn S

- ciężarem układu G

- siłą tłumienia T.

Podczas analizy siły sprężyn i ciężar pominięto. Siła tłumienia dla karkasu wykonanego $\mathrm{z}$ rezotexu jest rzędu $50 \mathrm{~N}$, a dla karkasu z aluminium rzędu 100 N, z uwagi na generowanie się prądów wirowych podczas ruchu cewki w polu magnetycznym.

Siłę bezwładności obliczano ze wzoru (1), gdzie: $\mathrm{m}=176 \mathrm{~g}$ - masa układu cewka-element łączący-zawory, napęd zblokowany, konfiguracja 1 , wariant 1 , jednakowe masy zaworów,

$\mathrm{m}=178,8 \mathrm{~g}$ - masa układu cewka-łącznik-zawory, napęd zblokowany, konfiguracja 1 , wariant $1,5 \%$ różnicy masy zaworów i elementu łączącego,

$\mathrm{m}=186 \mathrm{~g}-$ masa układu cewka-łącznik-zawory, napęd zblokowany, konfiguracja 1, wariant 2 ,

$\mathrm{m}=183 \mathrm{~g}$ - masa układu cewka-łącznik-zawory, napęd zblokowany, konfiguracja 1, wariant 3,

$\mathrm{m}=224 \mathrm{~g}-$ dla układu cewka-zawory, napęd zblokowany, konfiguracja 2,

Table 1. Material properties of coil elements Tabela 1. Właściwości materiałowe elementów cewki

\begin{tabular}{|c|c|c|c|c|c|}
\hline $\begin{array}{c}\text { Density/ } \\
\text { gestość } \rho \\
{\left[\mathrm{kg} / \mathrm{m}^{3}\right]}\end{array}$ & $\begin{array}{c}\text { Young module/ } \\
\text { modut Younga } \mathrm{E} \\
{[\mathrm{MPa}]}\end{array}$ & $\begin{array}{c}\text { Poisson } \\
\text { number/liczba } \\
\text { Poissona }[-]\end{array}$ & $\begin{array}{c}\mathrm{R}_{\mathrm{m}} \\
{[\mathrm{MPa}]}\end{array}$ & $\begin{array}{c}\mathrm{R}_{\mathrm{e}} \\
{[\mathrm{MPa}]}\end{array}$ & $\begin{array}{c}\mathrm{R}_{\text {bending }} \\
{[\mathrm{MPa}]}\end{array}$ \\
\hline 8900 & 117000 & 0.35 & 227 & 57 & - \\
\hline 2700 & 71000 & 0.27 & 420 & 290 & - \\
\hline 1300 & 7000 & 0.3 & - & - & 100 \\
\hline
\end{tabular}

$\mathrm{m}=113 \mathrm{~g}$ - masa układu cewka napędu-zawór wydechowy, napęd zintegrowany, karkas cewki ze stopu aluminium, $\mathrm{m}=103 \mathrm{~g}$ - masa układu cewka napędu-zawór wydechowy, napęd zintegrowany, karkas cewki z rezotexu [2], $\mathrm{m}=107 \mathrm{~g}$ - masa układu cewka napędu-zawór ssący, napęd zintegrowany, karkas cewki ze stopu aluminium, $\mathrm{m}=100 \mathrm{~g}$ - masa układu cewka napędu-zawór ssący, napęd zintegrowany, karkas cewki z rezotexu [2].

Czas t ruchu układu może być oszacowany z zależności (2), gdzie: $\mathrm{H}=7 \mathrm{~mm}$ - maksymalny wznios zaworu [3].

Siłę gazową oblicza się ze wzoru (3), gdzie: $d=27 \mathrm{~mm}$ - średnica średnia zaworu głowicy; wartość $27 \mathrm{~mm}$ jest charakterystyczna dla silników spalinowych w samochodach osobowych, $\mathrm{p}_{\mathrm{g}}=0,5 \mathrm{MPa}-$ ciśnienie gazów w cylindrze silnika, obciążające zawór wydechowy podczas otwierania.

Przyspieszenie cewki może być obliczane ze wzoru (4) [3].

Podczas symulacji ruchu układu cewka napędu-zawór, dla rozrządu pracującego poza silnikiem przyspieszenie 


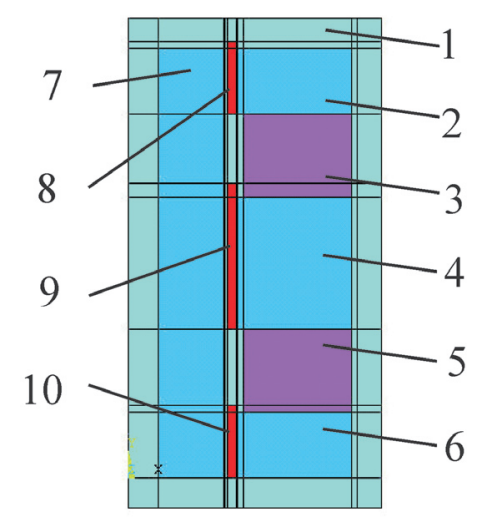

Fig. 5. The schematics of magnetoelectric drive for exhaust valve: 1 - air, 2, 4, 6 - pole shoe, 3, 5- sintered magnet, 7 - core, 8, 9, 10 - coil winding

Rys. 5. Schemat magnetoelektrycznego napędu zaworów wylotowych: 1 -powietrze, 2, 4, 6-nabiegunnik, 3, 5-magnes staty, 7-rdzeń, 8, 9, 10-uzwojenie cewki

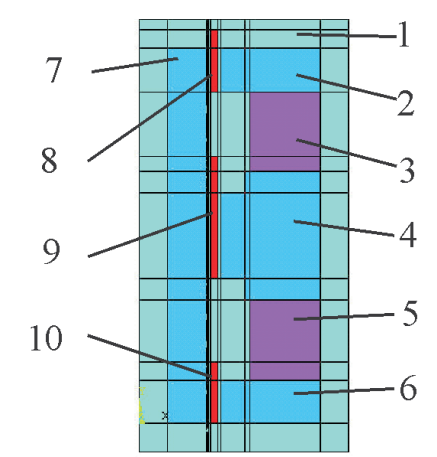

Fig. 6. The schematics of magnetoelectric drive for inlet valve, configuration $1 ; 1$ - air, 2, 4, 6 - pole shoe, 3, 5- sintered magnet, 7 - core, $8,9,10$ - coil winding

Rys. 6. Schemat magnetoelektrycznego napędu zaworów ssących, konfiguracja 1; 1-powietrze, 2, 4, 6-nabiegunnik, 3, 5-magnes stały, 7-rdzeń, 8, 9, 10-uzwojenie cewki

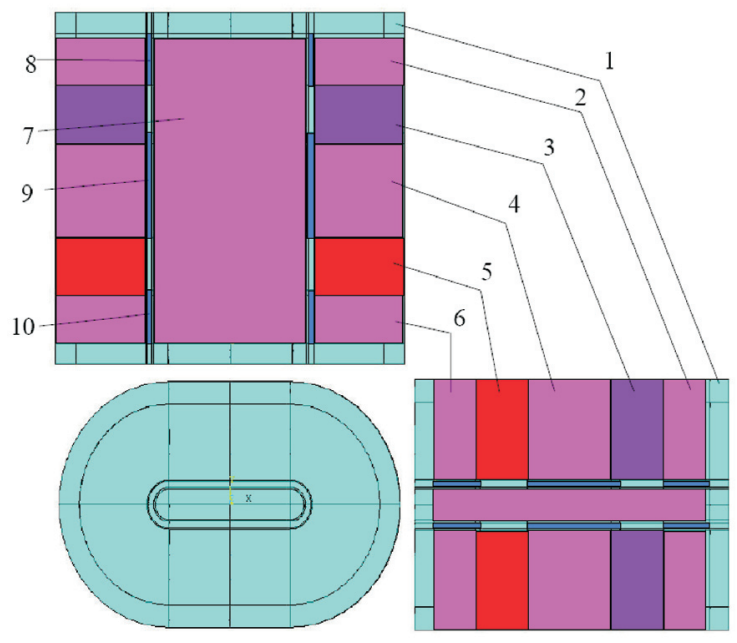

Fig. 7. The schematics of magnetoelectric drive for inlet valve, configuration $2 ; 1$ - air, 2, 4, 6 - pole shoe, 3, 5- sintered magnet, 7 - core, $8,9,10$ - coil winding

Rys. 7. Schemat magnetoelektrycznego napędu zaworów ssących, konfiguracja 2; 1 -powietrze, 2, 4, 6-nabiegunnik, 3, 5-magnes staty, 7-rdzeń, 8, 9, 10-uzwojenie cewki układu cewka napędu-zawór może być obliczane ze wzoru (5).

Gęstość materiału $\rho_{\mathrm{v}}$ cylindra obliczano ze wzoru (6).

Właściwości materiałowe elementów wchodzących w skład ruchomej cewki napędu przedstawiono w tabeli 1.

\section{Wyznaczanie sily elektrodynamicznej generowanej $w$ napędzie zblokowanym}

Do napędu dwóch zaworów ssących i wydechowych muszą być używane pojedyncze napędy zdolne do generowania różnych sił elektrodynamicznych. Siły w napędzie zaworów wydechowych muszą być większe od siły gazowej, z uwagi na występujące większe obciążenie tych zaworów. Schemat magnetoelektrycznego napędu zaworów wydechowych przedstawiono na rys 5 , a schemat magnetoelektrycznego napędu zaworów ssących na rys. 6 .

Do napędu zaworów wydechowych lub ssących można też używać napędu magnetoelektrycznego o innej konfiguracji ruchomej cewki. Schemat takiego napędu przedstawiono na rys. 7.

Do napędu zaworów ssących lub wydechowych można stosować także napęd zintegrowany (schemat rys. 8).

W czasie przepływu prądu w cewce napędu, poruszającej się w polu magnetycznym pochodzącym $\mathrm{z}$ obwodu magnetycznego magnesy stałe - nabiegunniki - szczeliny powietrzne jest generowana siła elektrodynamiczna skierowana wzdłuż osi cewki. Wartości siły elektrodynamicznej generowanej w napędzie wyznaczono metodą MES, przy wykorzystaniu komercyjnego oprogramowania. Celem uproszczenia analizy przyjęto model osiowosymetryczny.

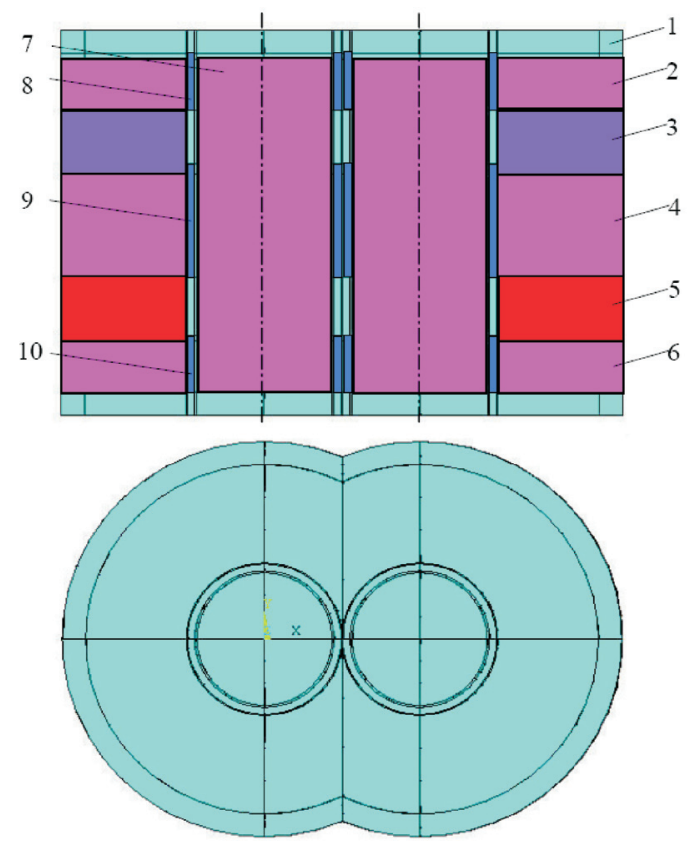

Fig. 8. The schematics of magnetoelectric drive for inlet valve, configuration 2; 1 - air, 2, 4, 6- pole shoe, 3, 5- sintered magnet, 7 - core, $8,9,10$ - coil winding

Rys. 8. Schemat zintegrowanego magnetoelektrycznego napędu zaworów rozrzadu: 1 -powietrze, 2, 4, 6-nabiegunnik, 3, 5-magnes staly, 7-rdzeń, 8, 9, 10-uzwojenie cewki 


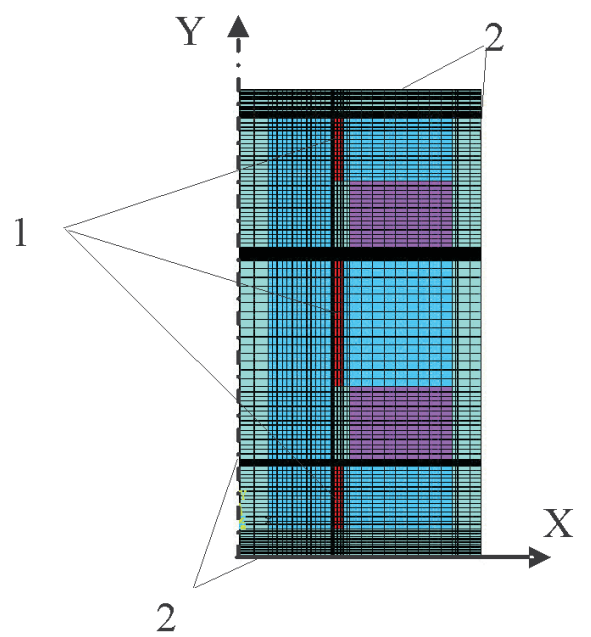

Fig. 9. The grid of finite elements and boundary conditions: 1 - areas containing nodes of elements, where homogeneous electric density $\rho$ has been introduced, 2 - lines containing nodes, where value of component of vector magnetic potential has been introduced $\mathrm{A}_{\mathrm{z}}=0$

Rys. 9. Siatka elementów skończonych i warunki brzegowe: 1 - pola zawierające węzly elementów skończonych, na których wprowadzono jednorodna gęstość elektryczna p, 2 - linie zawierajace węzly, na których wprowadzono wartość składowej wektorowego potencjału magnetycznego $A_{z}=0$

The following boundary conditions were used:

- homogeneous density $\rho$ was introduced in the nodes of finite elements lying on cross-section fields of the coil winding

- the value of component of vector magnetic potential $\mathrm{A}_{\mathrm{z}}=0$ was introduced in the nodes lying on the external lines limiting the area of air surrounding the drive.

A spatial model was used for the drive with coil of different configuration and for the integrated drive. The grid of finite elements was generated automatically by the program. It contained SOLID117 twenty-node spatial elements. The grid of finite elements is presented in Fig. 11.

The following boundary conditions were used:

- homogeneous density $\rho$ was introduced in the nodes of finite elements lying on cross-section fields of the coil winding

- the value of component of vector magnetic potential $\mathrm{A}_{\mathrm{z}}=0$ was introduced in the nodes lying on the external area fields limiting the area of air surrounding the drive.

The grid of finite elements and boundary conditions for the integrated drive are shown in Fig. 12.

As a result of the calculations, we obtained values of component of vector magnetic potential, on the basis of which it was possible to obtain the gradient of magnetic flux density.

On the basis of the magnetic induction values in the area of movable coil winding and the values of current flowing through the coil, the values of electrodynamic forces generated in the assembly were determined. The examples of gradient of values of component of vector magnetic potential for the exhaust valve drive are shown in Fig. 13, whereas for the inlet valve drive - in Fig. 14.
Wykorzystano płaski ośmiowęzłowy element skończony PLANE53, którego stopniami swobody były wartości składowej wektorowego potencjału magnetycznego AZ. Siatka elementów skończonych została wygenerowana automatycznie przez program. Siatkę elementów skończonych oraz warunki brzegowe dla napędu zaworów wydechowych przedstawiono na rys. 9, a dla napędu zaworów ssących na rys. 10 .

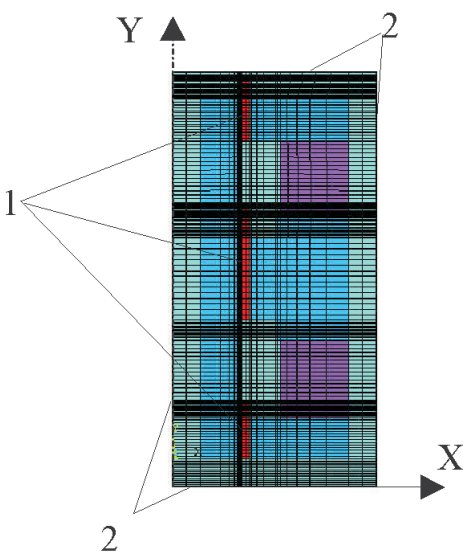

Fig. 10. The grid of finite elements and boundary conditions: 1 - areas containing nodes of elements, where homogeneous electric density $\rho$ has been introduced, 2 - lines containing nodes, where value of component of vector magnetic potential has been introduced $\mathrm{A}_{\mathrm{z}}=0$

Rys. 10. Siatka elementów skończonych $i$ warunki brzegowe: 1 - pola zawierające węzly elementów skończonych, na których wprowadzono jednorodna gęstość elektryczna $\rho, 2$ - linie zawierajace węzty, na których wprowadzono wartość składowej wektorowego potencjatu magnetycznego $A_{z}=0$

Użyto następujących warunków brzegowych:

- w węzłach elementów skończonych leżących na polach przekroju uzwojeń cewki wprowadzono jednorodną gęstość elektryczną $\rho$

- w węzłach leżących na zewnętrznych liniach, ograniczających obszar powietrza otaczającego napęd, wprowadzono wartość składowej wektorowego potencjału magnetycznego $\mathrm{A}_{\mathrm{z}}=0$.

Dla napędu z cewką o innej konfiguracji oraz w przypadku napędu zintegrowanego użyto modelu przestrzennego. Siatka elementów skończonych została wygenerowana automatycznie przez program. Zawierała ona dwudziestowęzłowe elementy przestrzenne SOLID117. Siatkę elementów skończonych pokazano na rys. 11 .

Użyto następujących warunków brzegowych:

- w węzłach elementów skończonych leżących na polach przekroju uzwojeń cewki wprowadzono jednorodną gęstość elektryczną $\rho$

- w węzłach leżących na zewnętrznych polach powierzchni, ograniczających obszar powietrza otaczającego napęd, wprowadzono wartość składowej wektorowego potencjału magnetycznego $\mathrm{A}_{\mathrm{z}}=0$.

Siatkę elementów skończonych i warunki brzegowe dla napędu zintegrowanego zamieszczono na rys. 12 .

W wyniku obliczeń uzyskano wartości wektorowego potencjału magnetycznego, a na ich podstawie rozkład indukcji magnetycznej. 


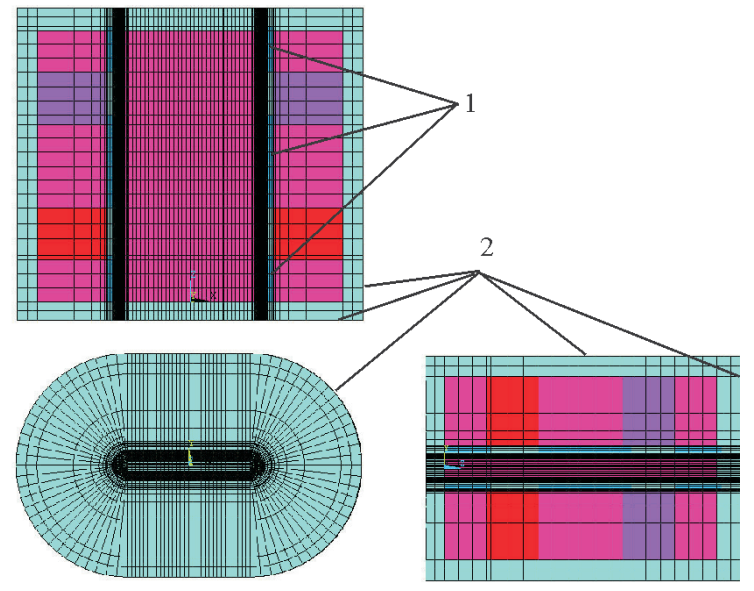

Fig. 11. The grid of finite elements and boundary conditions: 1 - areas containing nodes of elements, where homogeneous electric density $\rho$ has been introduced, 2 - lines containing nodes, where value of component of vector magnetic potential has been introduced $\mathrm{A}_{\mathrm{z}}=0$

Rys. 11. Siatka elementów skończonych $i$ warunki brzegowe: 1 - pola zawierajace węzty elementów skończonych, na których wprowadzono jednorodna gęstość elektryczna $\rho, 2$ - linie zawierajace węzły, na których wprowadzono wartość składowej wektorowego potencjału magnetycznego $A_{z}=0$

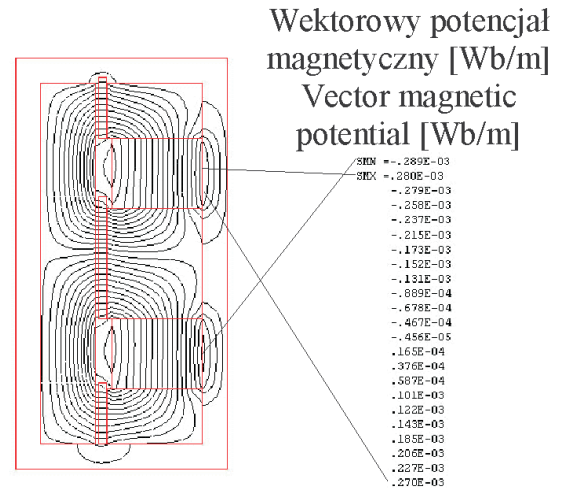

Fig. 13. The gradient of vector magnetic potential for the drive of the exhaust valves

Rys. 13. Rozkład wartości wektorowego potencjału magnetycznego dla napędu zaworów wydechowych

The examples of gradient of magnetic flux density for the exhaust valve drive are shown in Fig. 15, whereas for the inlet valve drive - in Fig. 16.

In the analyzed drives and for certain positions of the coil, there are zones of dispersed magnetic stream, which change as the coil moves and cause non-linear relationship between the electromagnetic force generated in the drive and the coil displacement. Moreover, in reality, the value of the magnetic field flux density is affected by the magnetic field appearing as the coil moves in the magnetic field.

Figure 17 shows the gradient of magnetic flux density for the drive with a movable coil of different configuration and Fig. 18 shows the gradient of magnetic flux density for the integrated drive of camshaft calves. The charts of electromagnetic forces showing valve displacement function are presented in Fig. 19.

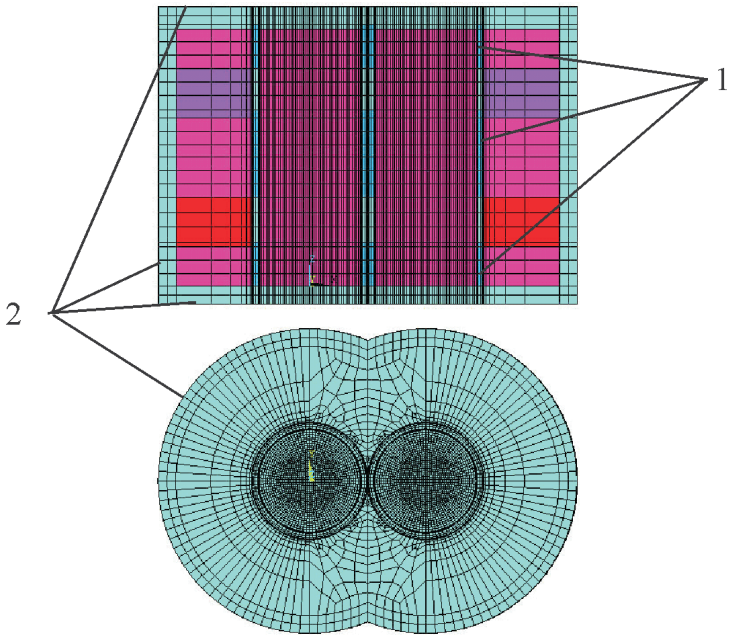

Fig. 12. The grid of finite elements and boundary conditions: 1 - areas containing nodes of elements, where homogeneous electric density $\rho$ has been introduced, 2 - lines containing nodes, where value of component of vector magnetic potential has been introduced $\mathrm{A}_{\mathrm{z}}=0$

Rys. 12. Siatka elementów skończonych $i$ warunki brzegowe: 1 - pola zawierajace węzły elementów skończonych, na których wprowadzono jednorodna gęstość elektryczna $\rho, 2$ - linie zawierające węzty, na których wprowadzono wartość składowej wektorowego potencjału magnetycznego $A_{z}=0$

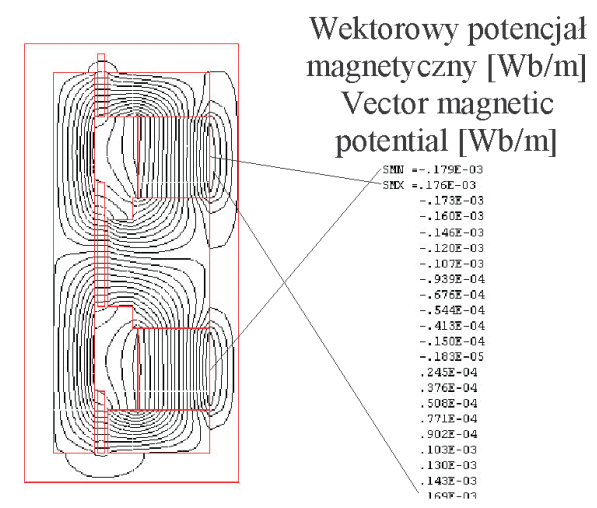

Fig. 14. The gradient of vector magnetic potential for the drive of the inlet valves

Rys. 14. Rozktad wektorowego potencjału magnetycznego dla napędu zaworów ssacych

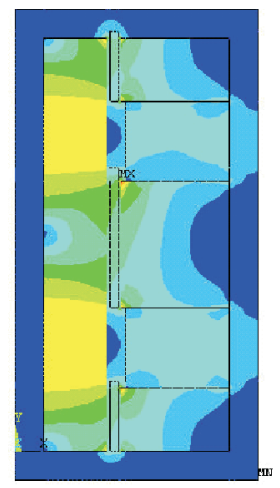

Indukcja magnetyczna [T]

Magnetic flux density [T]

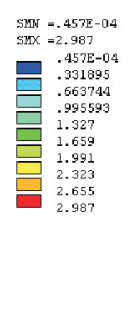

Fig. 15. The gradient of magnetic flux density for the drive of the exhaust valves

Rys. 15. Rozkład wartości indukcji magnetycznej dla napędu zaworów wydechowych 
In the case of a blocked drive, configuration 2 , in the area of moving drive coil there is the smallest value of magnetic flux density in relation to the other analyzed drive. This is the reason for obtaining of small values of electrodynamic forces and it predetermines the drive for driving of inlet valves only.

The relationship between the electrodynamic force and the current is shown in Fig. 20. It is almost linear.

Obtaining of the force of $600 \mathrm{~N}$ for the blocked drive, configuration 2 , is connected with the large value of the cur-

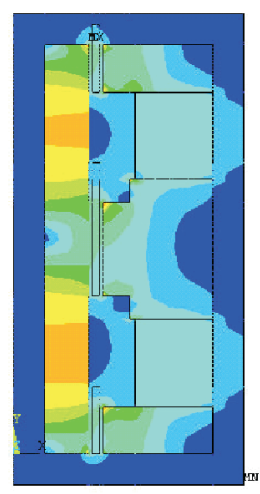

\section{Indukcja magnetyczna [T]} Magnetic flux density [T]

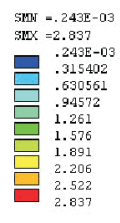

Fig. 16. The gradient of magnetic flux density for the drive of the inlet valves, configuration 1

Rys. 16. Rozkład wartości indukcji magnetycznej dla napędu zaworów ssacych, konfiguracja 1
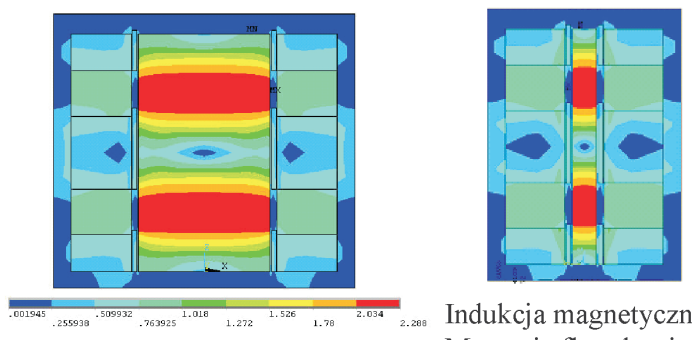

Indukcja magnetyczna [T] Magnetic flux density [T]

Fig. 17. The gradient of magnetic flux density for drive of valves, configuration 2

Rys. 17. Rozkład wartości indukcji magnetycznej dla napędu zaworów dla konfiguracji 2 cewki

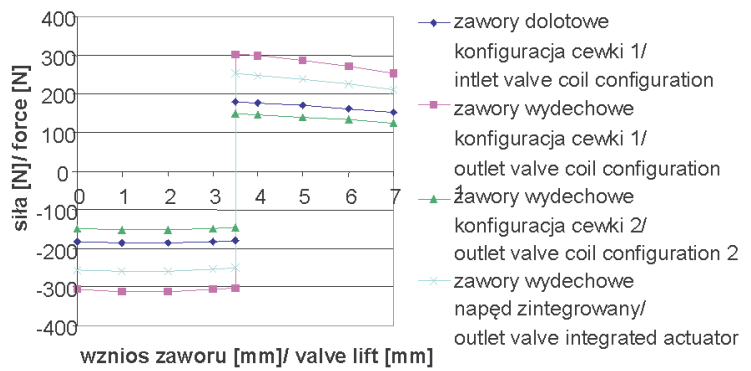

Fig. 19. Electrodynamic force vs. valve lift, for exhaust valve drive, for inlet valve drive of configuration 1 and 2, for integrated valve drive, when current in the coil winding is equal $20 \mathrm{~A}$

Rys. 19. Wykresy sil elektrodynamicznych w funkcji wzniosu zaworu dla napędu zaworów wydechowych i dla napędu zaworów ssących, dla konfiguracji cewki 1 i 2 oraz dla napędu zintegrowanego, dla przeptywu $w$ uzwojeniach cewki prądu $20 \mathrm{~A}$
Na podstawie indukcji magnetycznej w obszarze uzwojeń ruchomej cewki i wartości przepływającego w cewce prądu wyznaczono wartości sił elektrodynamicznych generowanych w układzie. Przykładowe rozkłady wartości wektorowego potencjału magnetycznego dla napędu zaworów wydechowych pokazano na rys. 13, a dla napędu zaworów ssących na rys. 14 .

Przykładowe rozkłady indukcji magnetycznej dla napędu zaworów wydechowych zamieszczono na rys. 15, a dla napędu zaworów ssących na rys. 16.

$\mathrm{W}$ analizowanych napędach występują, przy pewnych położeniach cewki, strefy rozproszonego strumienia magnetycznego, które zmieniają się podczas ruchu cewki, powodując nieliniową zależność siły elektrodynamicznej generowanej w napędzie od przemieszczenia cewki. Ponadto w rzeczywistości na wartość indukcji pola magnetycznego w obszarze cewki wpływa także pole magnetyczne pojawiające się podczas ruchu cewki w polu magnetycznym.

Na rysunku 17 przedstawiono rozkład indukcji magnetycznej dla napędu z ruchomą cewką o odmiennej konfiguracji, a na rys.18 - rozkład indukcji magnetycznej dla zintegrowanego napędu zaworów rozrządu. Wykresy sił elektrodynamicznych, w funkcji przemieszczenia zaworu, zamieszczono na rys. 19.

W przypadku napędu zblokowanego o konfiguracji 2, w obszarze poruszania się cewki napędu występuje najmniejsza
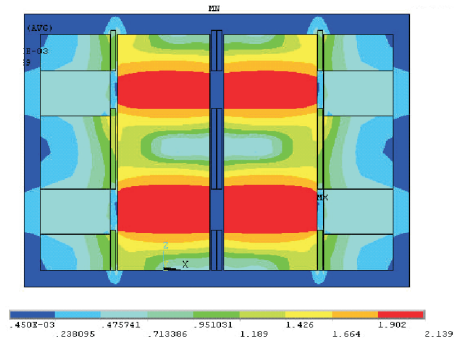

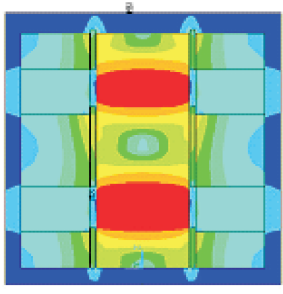

Indukcja magnetyczna [T] Magnetic flux density [T]
Fig. 18. The gradient of magnetic flux density for integrated drive of valves

Rys. 18. Rozkład wartości indukcji magnetycznej dla zintegrowanego napędu zaworów

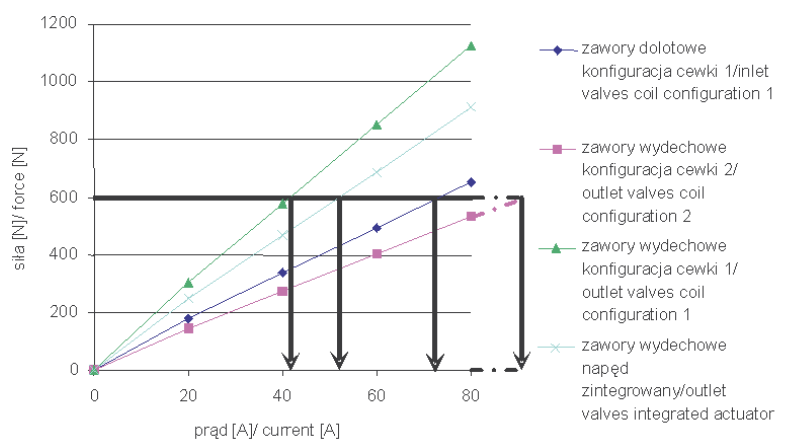

Fig. 20. Electrodynamic force vs current, for exhaust valve drive, for inlet valve drive of configuration 1 and 2

Rys. 20. Wykresy sit elektrodynamicznych w funkcji prądu dla napędu zaworów wydechowych i dla napędu zaworów ssacych, dla konfiguracji cewki 1 i 2 oraz dla napędu zintegrowanego 
rent in the coil and, as a result of this, the increase of winding temperature. Because of that, the drive operation under such large loads should not last long. In the case of the integrated drive, the axis of component of electrodynamic force shifts in relation to the axis of symmetry of the coil-valve assembly. The axes are shifted for the analyzed case by $0.9 \mathrm{~mm}$. This leads to creation of a torque affecting the coil-valve assembly and, as a result, it may lead to increase of resistances of motions between the valve stem and guide. The largest value of electrodynamic force is obtained in the integrated valve drive. The values of maximum lift of the drive coilvalve assembly for the values of the driving force of $400 \mathrm{~N}$ and the force of motion resistance of $100 \mathrm{~N}$ as calculated on the basis of the formulas (2) and (5) are presented in Table 2 . The calculations were made for inlet and exhaust valves with the assumption of differences in weights of the drive coil-valve assemblies amounting to $2 \%$.

The results of calculations indicate that the $2 \%$ change of the assembly weight caused $2 \%$ change of the valve lift. If we disregard the influence of the form material thickness upon the dynamics of the drive coil-valve assembly, the form material shall not affect the valve lift.

\section{The models of the drive-valve assembly used for the analysis of the motion parameters}

The analysis of motion parameters of the drive-valve assembly was conducted for several configurations of the blocked drive and the assembly including the integrated magnetoelectric drive. The analysis was conducted only for exhaust valves due to greater values of the driving force.

The schematics of the moving assembly: magnetoelectric drive coil, connecting element, two driven valves, is presented in Fig. 21. The analysis considered three variants of the element connecting drive and both valves. In the first variant, the drive coil form and element connecting valves with the drive were made of rexotex [2]. In the second variant the drive coil form made of rezotex [2] was connected to the element connecting both valves and made of aluminum alloy. In the third variant, which was similar to the second variant, additional ribs for stiffening of the element connecting valves were used.

The schematics of the second configuration of the moving assembly, in which the coil form of the blocked drive is connected to both valves without using a connecting element, is presented in Fig. 22.

The last analyzed assembly was the single assembly of integrated drive coil form-single valve. The schematics of the moving assembly is presented in Fig. 23.

In all analyzed cases the distance between valves axes was identical.

For all analyzed cases of the blocked drive, the geometry of the coil, connecting element and valves was the same. In the case of the blocked drive, configuration 2 , the length of the wartość indukcji magnetycznej, w stosunku do pozostałych analizowanych napędów. Jest to powód uzyskiwania małych sił elektrodynamicznych i predystynuje ten napęd do napędzania jedynie zaworów ssących.

Zależność siły elektrodynamicznej od prądu pokazano na rys. 20. Jest ona niemal liniowa.

Uzyskiwanie siły $600 \mathrm{~N}$ dla napędu zblokowanego o konfiguracji 2 jest związane $\mathrm{z}$ dużą wartością prądu $\mathrm{w}$ cewce i w efekcie wzrostem temperatury uzwojenia. $Z$ tego względu praca napędu przy tak dużych obciążeniach nie powinna trwać zbyt długo. W przypadku napędu zintegrowanego pojawia się przesunięcie osi działania wypadkowej siły elektrodynamicznej w stosunku do osi symetrii układu cewka-zawór. Przesunięcie tych osi dla analizowanego przypadku wynosi $0,9 \mathrm{~mm}$. Prowadzi to do powstawania momentu działającego na układ cewka-zawór i w rezultacie może wystąpić zwiększenie oporów ruchu między trzonkiem zaworu i prowadnicą. Największa siła elektrodynamiczna jest uzyskiwana w zintegrowanym napędzie zaworu. Obliczone na podstawie wzorów (2) i (5) wartości maksymalnego wzniosu układu cewka napędu-zawór, dla wartości siły napędowej $400 \mathrm{~N}$ i siły oporów ruchu $100 \mathrm{~N}$, przedstawia tabela 2. Obliczenia te wykonano dla zaworów ssących i wydechowych, zakładając różnice mas układów cewka napędu-zawór rzędu $2 \%$.

Wyniki obliczeń wskazują, że 2-procentowa zmiana masy układu powoduje 2-procentową zmianę wzniosu zaworu. Przy pominięciu wpływu sztywności materiału karkasu na dynamikę układu cewka napędu-zawór, rodzaj materiału karkasu nie ma wpływu na wznios zaworu.

\section{Modele układu napęd-zawory wykorzy- stywanego do analizy parametrów ruchu}

Analizę parametrów ruchu układu napęd-zawory przeprowadzono dla kilku konfiguracji układu zblokowanego oraz dla układu zawierającego zintegrowany napęd magnetoelektryczny. Analizę przeprowadzono jedynie dla zaworów wydechowych, z uwagi na występujące większe wartości siły napędzającej.

Schemat poruszającego się układu: cewka napędu magnetoelektrycznego, element łączący, dwa napędzane zawory zamieszczono na rys. 21. Podczas analizy rozpatrzono trzy warianty elementu łączącego napęd z oboma zaworami. W pierwszym wariancie karkas cewki napędu i element łączący zawory $\mathrm{z}$ napędem były wykonane $\mathrm{z}$ rezotexu [2]. W drugim wariancie
Table 2. Valve lift for different material and geometrical properties of the integrated drive

Tabela 2. Wznios zaworów dla różnych parametrów materiałowych i geometrii napędu zintegrowanego

\begin{tabular}{|l|c|c|c|c|}
\hline Assembly/uktad & \multicolumn{2}{|c|}{$\begin{array}{c}\text { Coil-inlet valve/ } \\
\text { cewka-zawór ssący }\end{array}$} & \multicolumn{2}{|c|}{$\begin{array}{c}\text { Coil-exhaust valve/ } \\
\text { cewka-zawór wydechowy }\end{array}$} \\
\hline $\begin{array}{l}\text { The coil form material/materiat } \\
\text { karkasu cewki }\end{array}$ & Rezotex & $\begin{array}{c}\text { Aluminum alloy/ } \\
\text { stop aluminium }\end{array}$ & Rezotex & $\begin{array}{c}\text { Aluminum alloy/ } \\
\text { stop aluminium }\end{array}$ \\
\hline Weight/masa $[\mathrm{g}]$ & 100 & 107 & 103 & 113 \\
\hline Lift/wznios & & \multicolumn{4}{|c|}{$[\mathrm{mm}]$} \\
\hline Assembly weight/masa układu $100 \%$ & 6.75 & 6.308 & 6.553 & 5.973 \\
\hline Assembly weight/masa układu $98 \%$ & 6.887 & 6.437 & 6.687 & 6.095 \\
\hline Difference/różnica $[\%]$ & 2.04 & 2.04 & 2.04 & 2.04 \\
\hline
\end{tabular}


coil winding and height of particular elements of the drive were the same as in the first configuration of the drive. The surface of pole shoes and magnets was also the same as in the first configuration.

In order to simplify the analysis two cylinder were used for modelling of Wright of the vales. The cylinders had a design density corresponding to the quotient of the valve

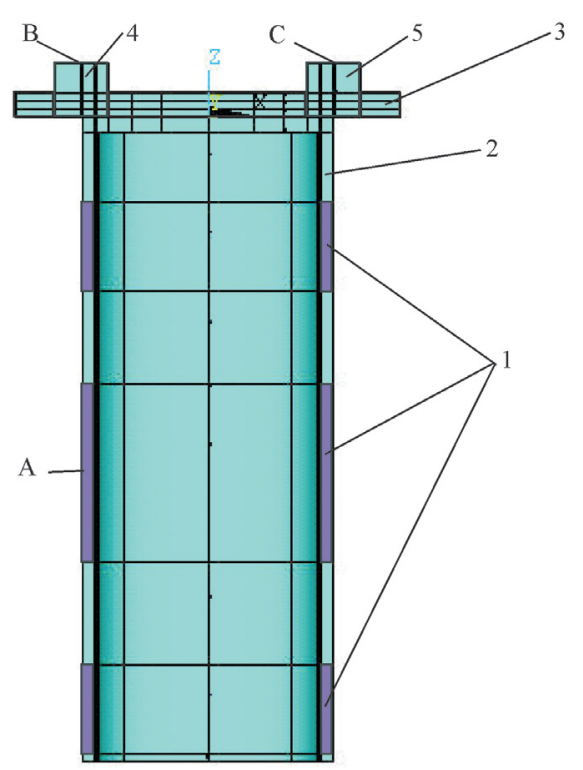

Fig. 21. The schematics of geometry of the assembly valves-magnetoelectric drive, configuration 1 , for the analysis of dynamic parameters of assembly motion; 1 - coil winding, 2 - coil form,

3 - connecting element, 4, 5-valves; A, B, C-points for calculation of parameters of motion

Rys. 21. Schemat geometrii układu zawory-napęd magnetoelektryczny, konfiguracja 1, do analizy parametrów ruchu układ; 1 -uzwojenie cewki, 2 - karkas cewki, 3 -element łaczacy, 4, 5-zawory; A, B, C-punkty do obliczén parametrów ruchu

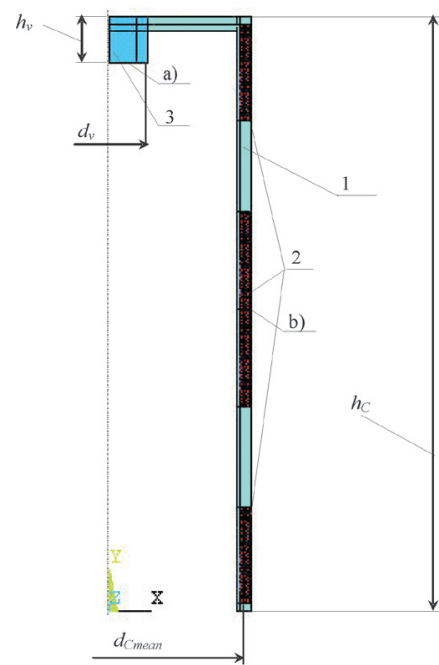

Fig. 23. The geometry for the model of drive-valve assembly; 1 - coil form, 2 - coil winding, 3 - driven valve, $\mathrm{d}_{v}$-diameter of valve stem,

$\mathrm{d}_{\text {Cmean }}$ - mean diameter of coil form, $\mathrm{h}_{\mathrm{C}}-$ height of coil form; points for calculation of motion parameters for: a) valve, b) coil form

Rys. 23. Geometria modelu układu napęd-zawór; 1 - karkas cewki, 2 uzwojenie cewki, 3 -zawór, $d_{v}$-średnica trzonka zaworu,

$d_{\text {Cmean }}$ - średnia średnica karkasu cewki, $h_{C}-$ wysokość karkasu cewki,

punkty do obliczania parametrów ruchu: a) zaworu, b) cewki karkas cewki napędu wykonany z rezoteksu [2] był połączony z elementem łączącym zawory wykonanym ze stopu aluminium. $\mathrm{W}$ trzecim wariancie, podobnym do drugiego, zastosowano dodatkowe żebra usztywniające element łączący zawory.

Schemat drugiej konfiguracji ruchomego układu, w którym karkas cewki napędu zblokowanego jest połączony z dwoma zaworami, bez użycia elementu łączącego przedstawiono na rys. 22 .

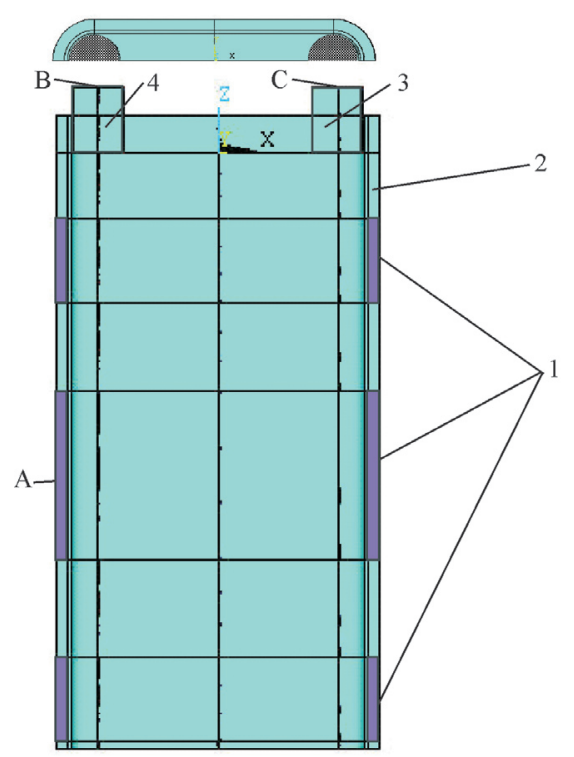

Fig. 22. The schematics of geometry of assembly valves-magnetoelectric drive, configuration 2 , for the analysis of dynamic parameters of assembly movement; 1 - coil winding, 2 - coil form, 3 - connecting element, 4, 5 - valves; A, B, C-points for calculation of the parameters of motion

Rys. 22. Schemat geometrii układu zawory-naped magnetoelektryczny, konfiguracja 2, do analizy parametrów ruchu układu; 1 -uzwojenie cewki, 2-karkas cewki, 3, 4-zawory; A, B, C-punkty do obliczeń parametrów ruchu

Jako ostatni modelowano ruchomy układ pojedynczy karkas cewki napędu zintegrowanego-pojedynczy zawór. Schemat ruchomego układu przedstawia rys. 23.

We wszystkich analizowanych przypadkach zachowano jednakową odległość osi zaworów.

Dla wszystkich analizowanych przypadków napędu zblokowanego geometria cewki, elementu łączącego i zaworów były takie same. W przypadku napędu zblokowanego o drugiej konfiguracji zachowano długość uzwojeń cewki oraz wysokości poszczególnych elementów napędu takie same jak w pierwszej konfiguracji napędu. Również powierzchnia nabiegunników, magnesów były takie same jak w pierwszej konfiguracji.

W celu uproszczenia analizy, w przypadku napędu zblokowanego, do zamodelowania masy zaworów użyto dwóch walców, którym przypisano gęstość obliczeniową odpowiadającą ilorazowi masy zaworu przez objętość wspomnianego walca. Również w celu uproszczenia analizy wykorzystano symetrię układu. Analizę dynamiki układu złożonego z ruchomej cewki napędu, elementu łączącego i dwóch zaworów wykonano metodą elementów skończonych. 
weight by density of the above-mentioned cylinder. The analysis was also simplified by the use of assembly symmetry. The analysis of the dynamics of the assembly combined of movable drive coil, connecting element and two valves, was made with the use of the method of finite elements. The analysis used SOLID185 eight-node finite element [1]. The degrees of freedom for the element constituted $u_{x}, u_{y}$, $\mathrm{u}_{\mathrm{z}}$ displacements in the Cartesian coordinate system. The boundary condition was realized by an introduction of load equal to the electrodynamic force generated in the drive into the nodes of elements lying within the movable coil winding. The force was evenly distributed to all nodes of the elements. Additionally, the condition of symmetry in the geometrical surface of the assembly symmetry was introduced. As an initial condition, the rest of the assembly was assumed.

The grid of finite elements was generated automatically by the program.

For the integrated drive, the axis symmetrical model was used. In this case, the analysis of dynamics also used the method of finite elements. PLANE82 eight-node elements were used with their degrees of freedom constituting $u_{x}, u_{y}$ displacements. The boundary condition was realized by an introduction of load equal to the electrodynamic force generated in the drive into the nodes of elements lying within the movable coil winding. The force was evenly distributed to all nodes of the elements. As an initial condition, the rest of the assembly was assumed.

In all analyzed cases the grid of finite elements was generated automatically by the program.

The schematics of the grid of finite elements and boundary conditions for variant 1 , configuration 1 of the coil was presented in Fig. 24, for variant 2 - in Fig. 25 and for variant 3 - in Fig. 26. The grid of finite elements and boundary conditions for the coil, configuration 2 was presented in Fig. 27 and for the integrated assembly - in Fig. 28.

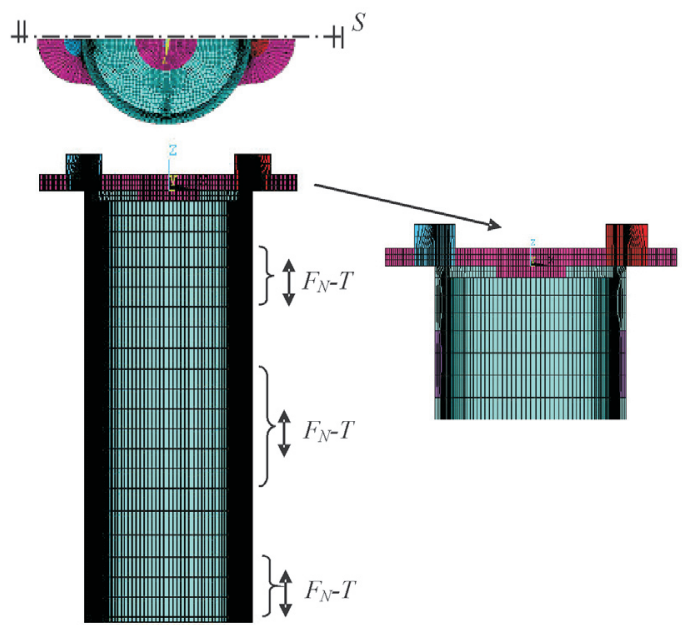

Fig. 25. Finite element grid and boundary conditions, configuration 1, variant $2 ; \mathrm{S}-$ symmetry, $\mathrm{F}_{\mathrm{N}}$ - loading force, $\mathrm{T}$ - damping force

Rys. 25. Siatka elementów skończonych $i$ warunki brzegowe w modelu, konfiguracja 1, wariant 2 ; $S$-symetria, $F_{N}$ - siła napędowa, $T$ - siła ttumienia
W czasie analizy wykorzystano ośmiowęzłowy element skończony SOLID185 [1]. Stopniami swobody takiego elementu były przemieszczenia $u_{x}, u_{y}, u_{z}$ w układzie kartezjańskim. Jako warunek brzegowy wprowadzono w węzłach elementów leżących w obszarze uzwojenia ruchomej cewki obciążenie równe sile elektrodynamicznej generowanej $\mathrm{w}$ napędzie, równomiernie rozłożonej na wszystkie węzły tych elementów. Ponadto wprowadzono warunek symetrii w geometrycznej płaszczyźnie symetrii układu. Jako warunek początkowy przyjęto spoczynek układu.

Siatka elementów skończonych została wygenerowana automatycznie przez program.

Dla napędu zintegrowanego wykorzystano model osiowosymetryczny. W tym przypadku do analizy dynamiki wykorzystano również metodę elementów skończonych. Użyto ośmiowęzłowego elementu PLANE82, którego stopniami swobody były przemieszczenia $u_{x}, u_{y}$. Jako warunek brzegowy wprowadzono w węzłach elementów leżących w obszarze uzwojenia ruchomej cewki obciążenie równe sile elektrodynamicznej, generowanej w napędzie równomiernie rozłożonej na wszystkie węzły tych elementów. Jako warunek początkowy przyjęto spoczynek układu.

We wszystkich analizowanych przypadkach siatka elementów skończonych została wygenerowana automatycznie przez program.

Schemat siatki elementów skończonych i warunki brzegowe dla wariantu 1 konfiguracji 1 cewki zamieszczono na rys. 24 , dla wariantu 2 na rys. 25 , a dla wariantu 3 na rys. 26. Dla konfiguracji 2 cewki siatka elementów skończonych i warunki brzegowe przedstawiono na rys. 27 , a dla układu zintegrowanego na rys. 28.

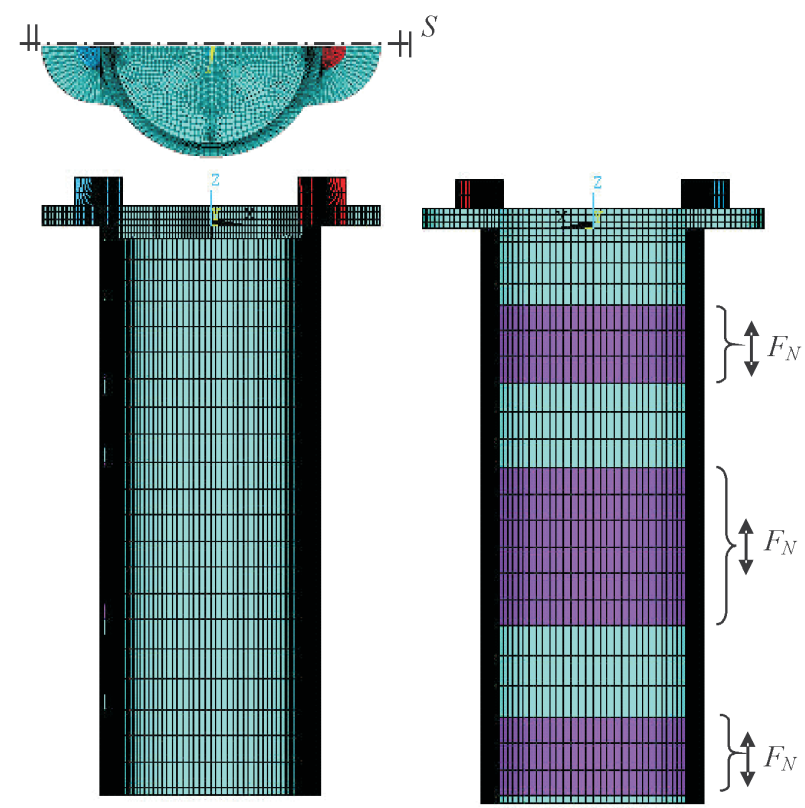

Fig. 24. Finite element grid and boundary conditions, configuration 1, variant $1 ; \mathrm{S}$ - symmetry condition, $\mathrm{F}_{\mathrm{N}}$ - loading force

Rys. 24. Siatka elementów skończonych $i$ warunki brzegowe $w$ modelu konfiguracja 1 , wariant 1 ; $S$-warunek symetrii, $F_{N}-$ siła napędowa 


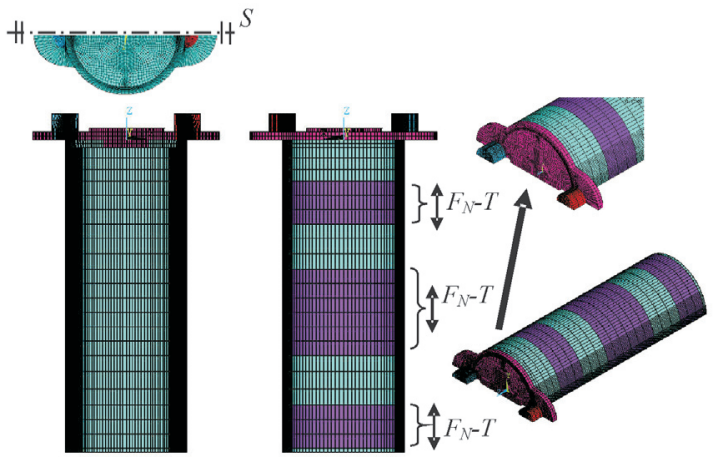

Fig. 26. Finite element grid and boundary conditions, configuration 1, variant $3 ; \mathrm{S}$ - symmetry, $\mathrm{F}_{\mathrm{N}}$ - loading force, $\mathrm{T}$ - damping force

Rys. 26. Siatka elementów skończonych i warunki brzegowe w modelu, konfiguracja 1 , wariant $3 ; S$-symetria, $F_{N}$ - siła napędowa, $T$ - siła thumienia

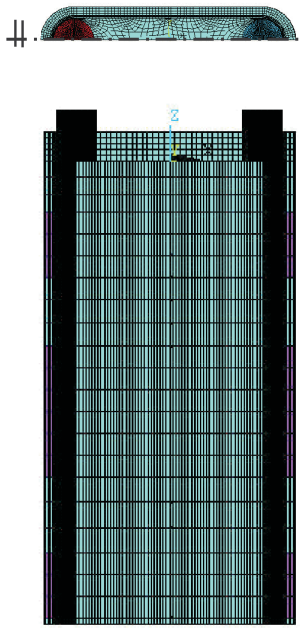
$H^{S}$

Fig. 27. Finite element grid and boundary conditions, configuration 2 : $\mathrm{S}$ - symmetry, $\mathrm{F}_{\mathrm{N}}$ - loading force, $\mathrm{T}$ - damping force

Rys. 27. Siatka elementów skończonych $i$ warunki brzegowe $w$ modelu, konfiguracja 2: $S$ - warunek symetrii, $F_{N}$ - siła napędowa, $T$-siła tlumienia

\section{The analysis of dynamics of the drive-valves assembly}

In all analyzed steel valves driven by the blocked or integrated drives, the identical course of FM electrodynamic force generated in the magnetoelectric drive was used (Fig. 29).

In order to verify the influence of difference in loads of both valves driven by one drive as exerted upon dynamics of the vales and movable coil, the difference in density of $5 \%$ was applied. The above-mentioned differences in loads may result from the difference between weights of the valves, resistance forces in the guide and non-identical stiffness of connections between the valves and the connecting element. Therefore we also verified the case, in which both valves had the same densities and one of them was additionally loaded with the force of $50 \mathrm{~N}$.

A slightly different course of the driving force was used for the integrated drive as shown in Fig. 30.

The charts of the valve lift, its speed and acceleration as driven by the integrated drive are shown in Fig. 30. Figures 31-35 present charts of the valve lift, its speed and acceleration for the blocked drive, configuration 1 respectively:

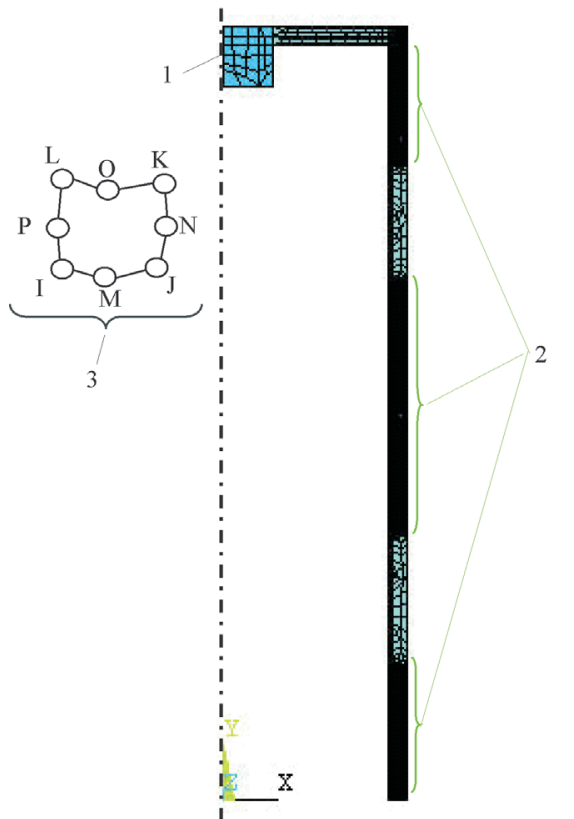

Fig. 28. The grid of elements, finite element, boundary conditions for the model of integrated drive coil-valve assembly: 1 - degree of freedom $\mathrm{u}_{\mathrm{x}}=0$ for nodes lying on $\mathrm{Y}$ axis, $2-$ the component of electrodynamic force and damping force $F_{M-T}^{\text {component }}=\left(F_{M}-T\right) / 128$, located at the center of each winding, 3 - PLANE82 finite element [4]

Rys. 28. Siatka elementów, element skończony, warunki brzegowe dla modelu układu cewka napędu zintegrowanego-zawór: 1 - stopień swobody $u_{x}=0$ dla węzłów leżacych na osi Y, 2 - składowa sity elektrodynamicznej i sity ttumienia $\mathrm{F}_{\mathrm{M}-\mathrm{T}}^{\text {component }}=\left(\mathrm{F}_{\mathrm{M}}-\mathrm{T}\right) / 128$, umieszczona $w$ środku każdego uzwojenia, 3 - element skończony PLANE82 [4]

\section{Analiza dynamiki układu napęd-zawory}

We wszystkich analizowanych zaworach stalowych, napędzanych przez napęd zblokowany lub zintegrowany, wykorzystywano jednakowy przebieg siły elektrodynamicznej FM generowanej w napędzie magnetoelektrycznym (rys. 29).

Dla sprawdzenia wpływu istnienia różnicy obciążenia dwóch zaworów napędzanych przez jeden napęd na dynamikę zaworów i ruchomej cewki wprowadzono różnicę gęstości zaworów na poziomie 5\%. Wspomniane różnice obciążenia mogą wynikać z różnicy mas zaworów, sił oporów ruchu w prowadnicy i niejednakowej sztywności połączeń zaworów z elementem łączącym. W tym samym celu sprawdzono także przypadek, gdy oba zawory miały jednakowe gęstości, ale jeden z nich był dodatkowo obciążany siłą $50 \mathrm{~N}$.

Dla napędu zintegrowanego zastosowano nieco inny przebieg siły napędowej, przedstawiony na rys. 30 .

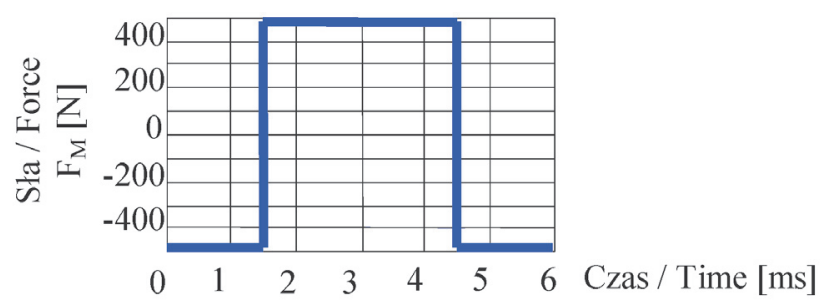

Fig. 29. The schematics of electrodynamic force FM, generated in a magnetoelectric drive

Rys. 29. Schemat sity elektromagnetycznej FM, generowanej w napędzie magnetoelektrycznym 

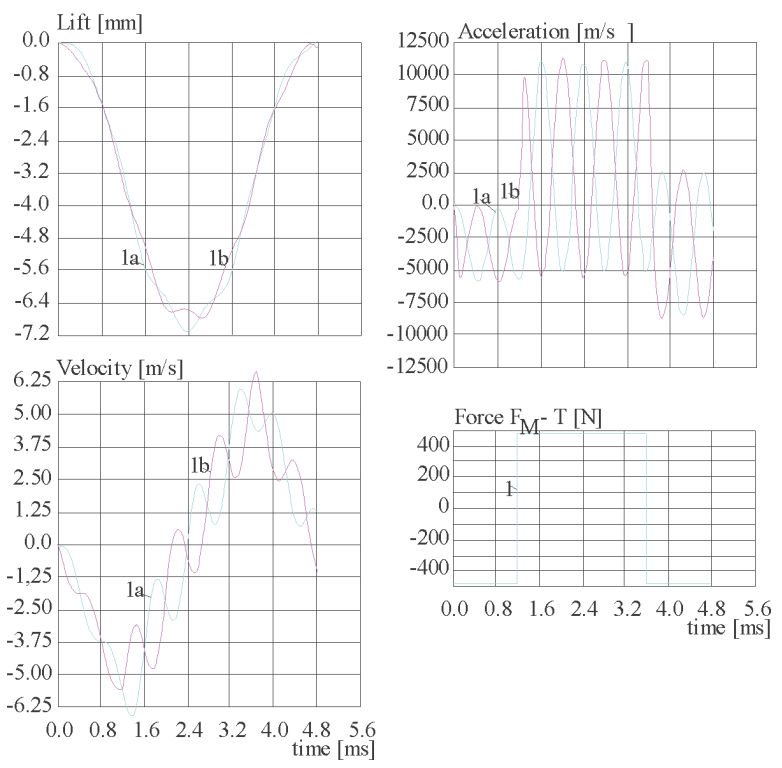

Fig. 30. The loading force, acceleration, velocity and lift vs time for exhaust valve-integrated drive coil assembly; a) for the valve

- in the point positioned in $h_{v}, b$ ) for the coil form - in the point positioned in $0.5 \cdot \mathrm{h}_{\mathrm{c}}$

Rys. 30. Siła napędowa, przyspieszenie, prędkość $i$ wznios zaworu $w$ funkcji czasu dla uktadu zawór wydechowy-cewka napędu zintegrowanego; a) dla zaworu - w punkcie umieszczonym na wysokości hv, b) dla

karkasu cewki-w punkcie umieszczonym na wysokości $0,5 \cdot h_{c}$

Figure 31 - variant 1, identical weights and valves load, Figure 32 - variant $1.5 \%$ difference between the valves weight,

Figure 33 - variant 1, identical weights of valves, valves load differs by $50 \mathrm{~N}$,

Figure 34 - variant 2 , identical weights of valves, Figure 35 - variant 3 , identical weights of valves.

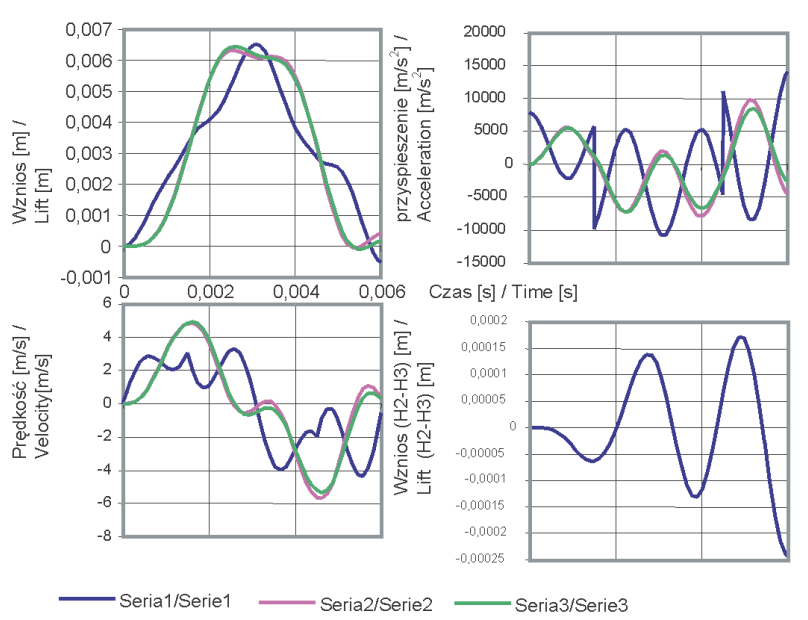

Fig. 32. Lift, velocity, acceleration vs. time for exhaust valve-coil assembly; blocked drive, configuration 1 , variant 1 , for the valve mass difference equal 5\%; A, B, C-points for calculation

Rys. 32. Wznios, prędkość, przyspieszenie elementów układu cewka-zawory, napęd zblokowany, konfiguracja 1, wariant 1, dla 5-procentowej różnicy mas zaworów; $A, B, C$-punkty obliczeniowe
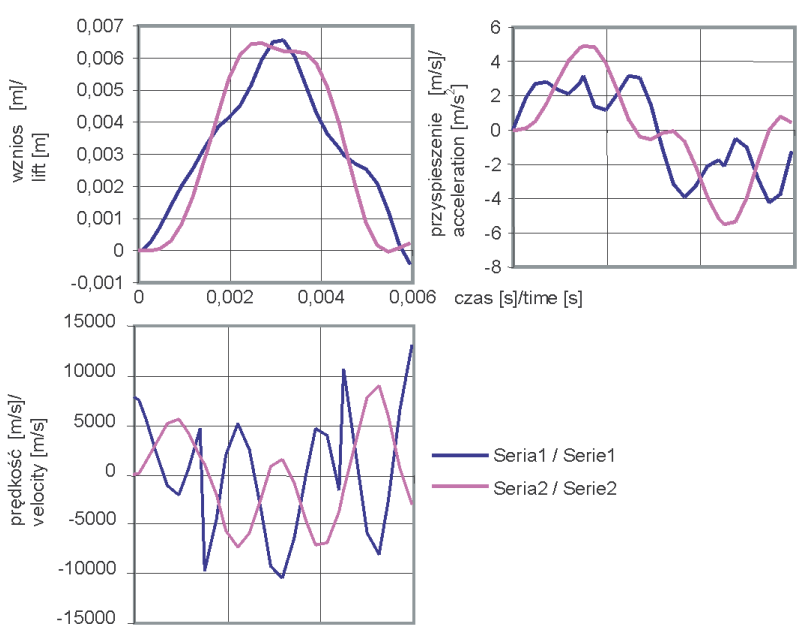

Fig. 31. Lift, velocity, acceleration vs time for exhaust valve-coil assembly, blocked drive, configuration 1 , variant 1 , symmetrical mass and loading of valves; A, B, C-points for calculation

Rys. 31. Wznios, prędkość i przyspieszenie elementów układu cewka-zawory, napęd zblokowany, konfiguracja 1, wariant 1, symetryczne masy i obciążenie zaworów; $A, B, C$-punkty obliczeniowe

Wykresy wzniosu zaworu, jego prędkości i przyspieszenia, napędzanych przez napęd zintegrowany przedstawia rys. 30. Rysunki 31-35 przedstawiają wykresy wzniosu zaworu, jego prędkości i przyspieszenia dla napędu zblokowanego o konfiguracji 1, odpowiednio:

rys 31 - wariant 1 , jednakowe masy i obciążenie zaworów,

rys. 32 - wariant 1, 5-procentowa różnica mas zaworów, rys. 33 - wariant 1 , masy zaworów jednakowe, obciążenie zaworów różni się o $50 \mathrm{~N}$,

rys. 34 - wariant 2 , masy zaworów jednakowe,

rys. 35 - wariant 3 , masy zaworów jednakowe.

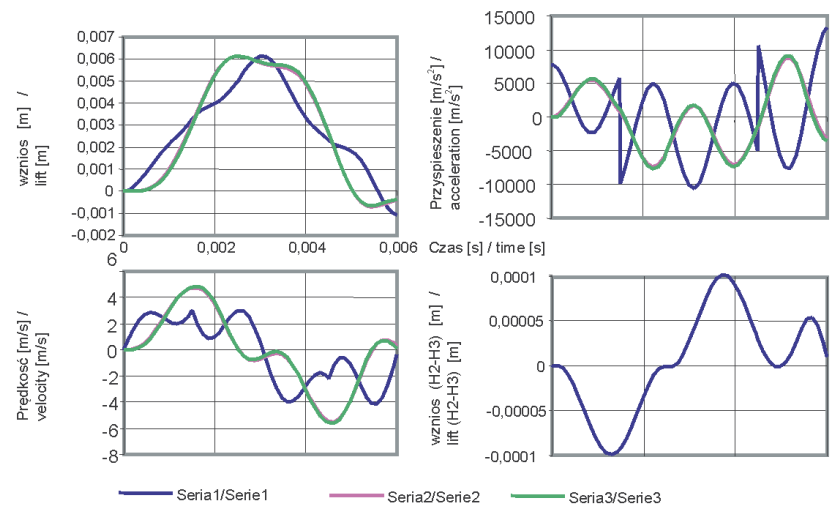

Fig. 33. Lift, velocity, acceleration vs time for exhaust valve-coil assembly, blocked drive, configuration 1 , variant 1 , for the difference of forces of valve motion resistance equal $50 \mathrm{~N}$; A, B, C-points for calculation

Rys. 33. Wznios, prędkość, przyspieszenie elementów układu cewka-zawory, napęd zblokowany, konfiguracja 1, wariant 1 , różnica sil oporów ruchu zaworów $50 \mathrm{~N}$; $\mathrm{A}, \mathrm{B}, \mathrm{C}$-punkty obliczeniowe 


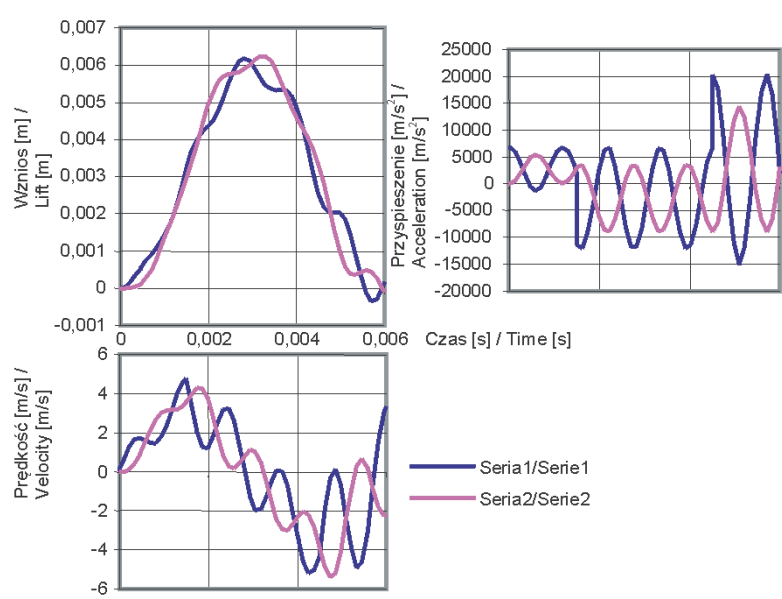

Fig. 34. Lift, velocity, acceleration vs time for exhaust valve-coil assembly, blocked drive, configuration 1, variant 2; A, B, C-points for calculation

Rys. 34. Wznios, prędkość, przyspieszenie elementów układu cewka-zawory, napęd zblokowany, konfiguracja 1, wariant 2 ; $A, B, C$-punkty obliczeniowe

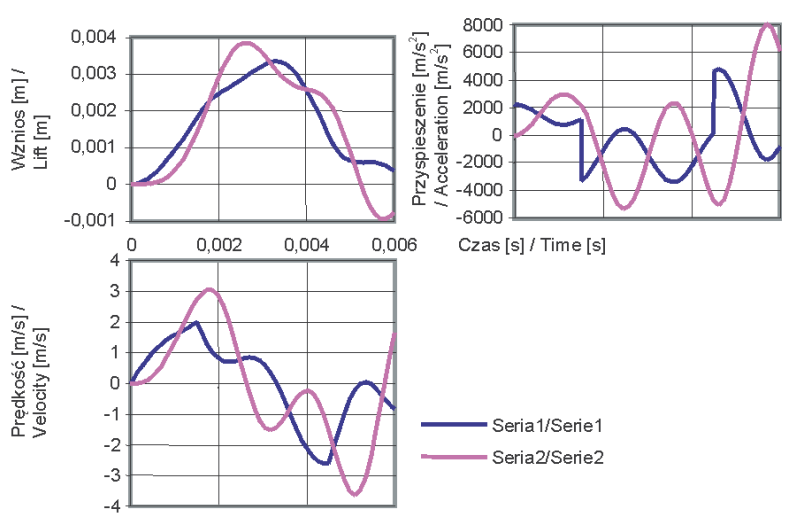

Fig. 36. Lift, velocity, acceleration vs. time for exhaust valve-coil assembly, blocked drive, configuration 2; A, B, C-points for calculation

Rys. 36. Wznios, prędkość i przyspieszenie elementów układu cewka-zawory, napęd zblokowany, konfiguracja 2

Figure 36 presents charts of the valve lift, its speed and acceleration for the blocked drive, configuration 2 .

Examples of gradient of stresses in the elements of valveblocked drive assembly are presented respectively in: Figure 37 - blocked drive, configuration 1, variant 1, Figure 38 - blocked drive, configuration 1, variant 2, Figure 39 - blocked drive, configuration 2,

Figure 40 - integrated drive.

The lift chart for the example of cam drive is shown in Fig. 41. The tolerance of maximum lift of the valve is 0.2 $\mathrm{mm}$. The depth of hardened layer is $2 \mathrm{~mm}$, which is the range, in which wear and tear of cam summits is commonly found. If the limit is exceeded, cams are subject to quicker wear and tear and the valve stroke may even by decreased by $5 \mathrm{~mm}$ or more [4].

For the blocked drive, configuration 1, variant 1, the difference between maximum lifts of the driven valves is more affected by the difference between weights than by the difference between resistances of motion between the valve stems and their guides. The greatest differences between

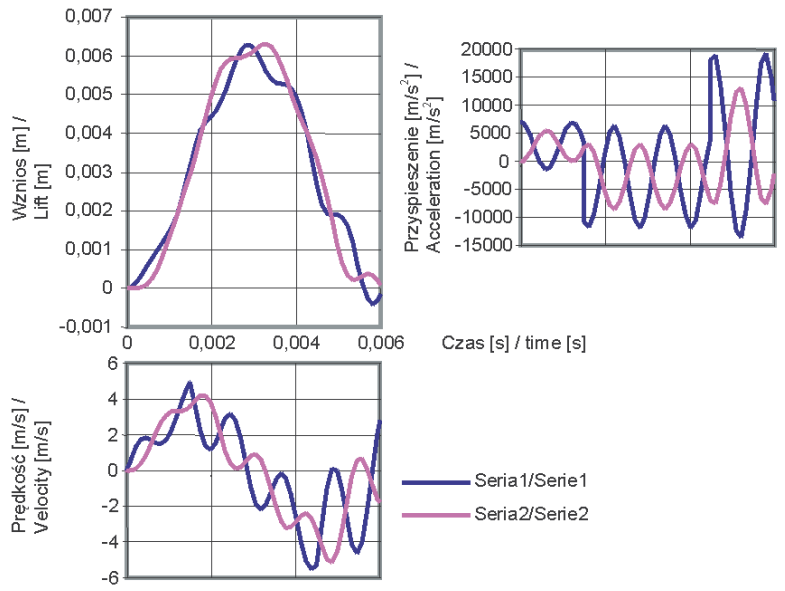

Fig. 35. Lift, velocity, acceleration vs. time for exhaust valve-coil assembly, blocked drive, configuration 1, variant 3; A, B, C-points for calculation

Rys. 35. Wznios, prędkość i przyspieszenie elementów uktadu cewka-zawory, napęd zblokowany, konfiguracja 1, wariant 3

$\mathrm{Na}$ rysunku 36 przedstawiono natomiast wykresy wzniosu zaworu, jego prędkości i przyspieszenia dla napędu zblokowanego o konfiguracji 2.

Przykładowe rozkłady naprężeń wypadkowych, w elementach układu zawory-napęd zblokowany, przedstawiają odpowiednio:

rys. 37 - napęd zblokowany, konfiguracja 1, wariant 1 , rys. 38 - napęd zblokowany, konfiguracja 1, wariant 2, rys. 39 - napęd zblokowany, konfiguracja 2, rys. 40 - napęd zintegrowany.

Wykres wzniosu dla przykładowego napędu krzywkowego pokazano na rys. 41. Tolerancja maksymalnego wzniosu zaworu wynosi 0,2 mm. Głębokość warstwy zahartowanej wynosi do $2 \mathrm{~mm}$ i w tym zakresie spotyka się najczęściej normalne zużycie ścierne wierzchołków krzywek. Po przekroczeniu tej granicy następuje znacznie szybsze zużycie krzywek i zmniejszenie skoku zaworu nawet o 5 i więcej $\mathrm{mm}$ [4].

Dla napędu zblokowanego o konfiguracji 1 i wariancie 1, na różnicę maksymalnych wzniosów napędzanych zaworów ma większy wpływ różnica mas niż różnica oporów ruchu między trzonkami zaworów i ich prowadnicami. Największe różnice między przemieszczeniami zaworów i karkasem cewki uzyskano dla napędu zblokowanego o konfiguracji 2. Był to też najcięższy z układów. Największe różnice między maksymalnymi przemieszczeniami zaworów i karkasem cewki występują dla napędu zblokowanego o konfiguracji 2, a najmniejsze dla konfiguracji 1, wariant 3. Największy wznios zaworu uzyskano dla zaworu napędzanego przez napęd zintegrowany.

W odniesieniu do napędów zblokowanych o konfiguracji 1 należy zapewnić odpowiedni docisk elementu łączącego do denka karkasu cewki, aby zapobiec zmniejszeniu sztywności układu. W przypadku elementu łączącego wykonanego z rezotexu [2] wartość tego docisku powinna wynosić co najmniej 4,2 MPa, zaś dla elementu łączącego ze stopu aluminium przynajmniej $12 \mathrm{MPa}$. 


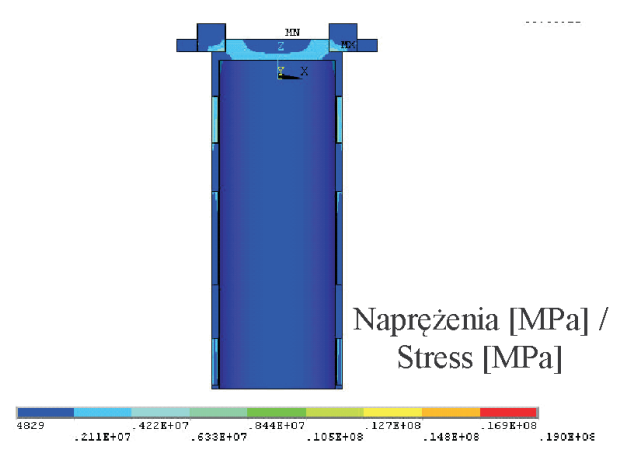

Fig. 37. Gradient of stresses in the elements of valve-blocked drive assembly, configuration 1 , variant 1

Rys. 37. Rozkład naprężeń wypadkowych w elementach układu zawory-napęd zblokowany, konfiguracja 1, wariant 1

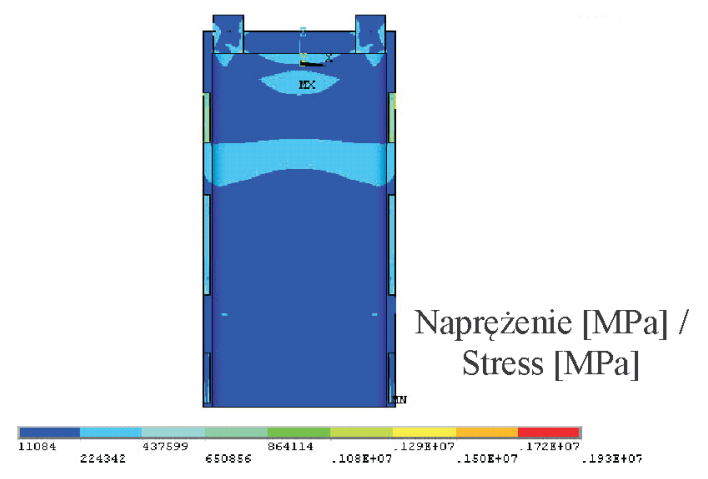

Fig. 39. Gradient of stresses in the elements of valve-blocked drive assembly, configuration 2

Rys. 39. Rozkład naprężeń wypadkowych w elementach uktadu zawory-naped zblokowany, konfiguracja 2

displacements of valves and the coil form were obtained for the blocked drive, configuration 2 . This was also the heaviest of the drives. The greatest differences between maximum displacements of valves and the coil form were obtained for the blocked drive, configuration 2, whereas the smallest differences were obtained for configuration 1 , variant 3 . The largest lift of the valve was obtained for the valve driven by the integrated drive.

As regards the blocked drives, configuration 1, one should ensure appropriate tightening of the connecting element to the bottom of the coil form in order to prevent decrease of stiffness of the assembly. In the case the connecting element is made of rezotex [2] the tightening value should be at least 4.2 $\mathrm{MPa}$, whereas for the connecting element made of aluminum alloy should be at least $12 \mathrm{MPa}$.

\section{Conclusions}

1. The difference between maximum lifts of inlet or exhaust valves driven by magnetoelectric blocked drive is more affected by the difference between weights than the difference between resistances of motion between stems of the valves and its guides.

2. For the driving of valves by means of an integrated drive with identical values of electromagnetic force and motion resistances, the difference between weights of the driven

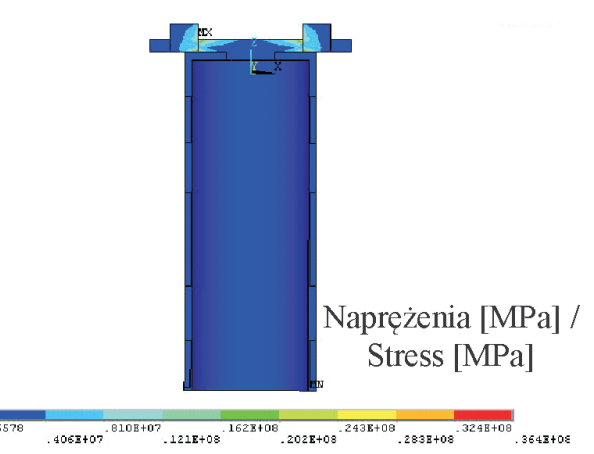

Fig. 38. Gradient of stresses in the elements of valve-blocked drive assembly, configuration 1 , variant 2

Rys. 38. Rozkład naprężeń wypadkowych w elementach uktadu zawory-napęd zblokowany, konfiguracja 1, wariant 2

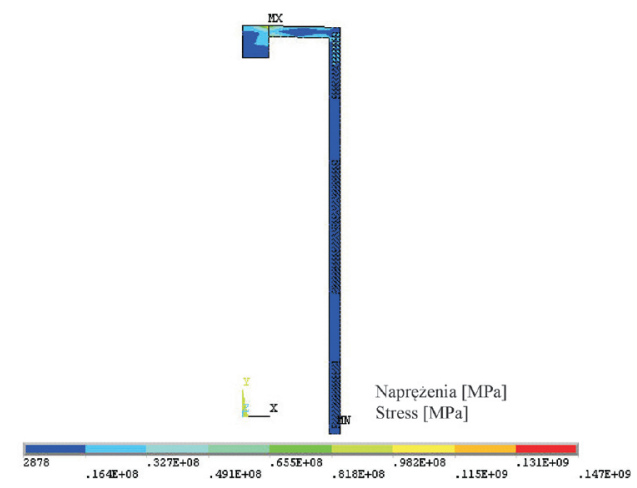

Fig. 40. Gradient of stresses in the elements of valve- integrated drive coil assembly

Rys. 40. Rozkład naprężeń wypadkowych w elementach układu zawór-napęd zintegrowany

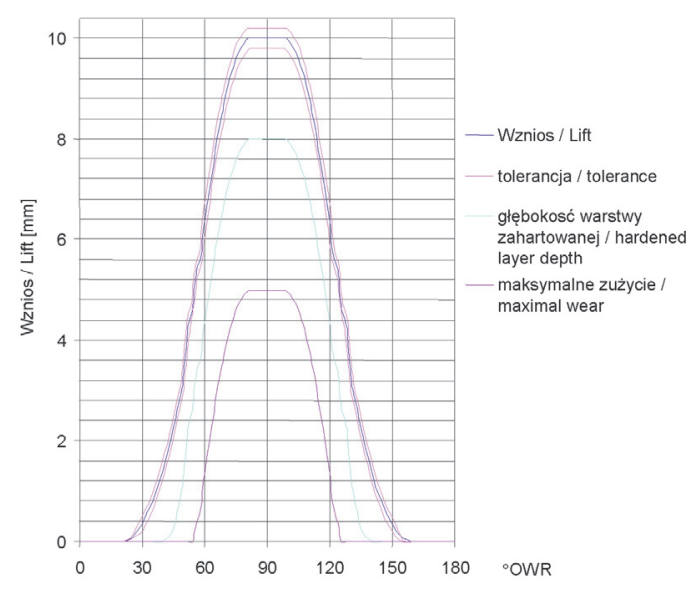

Fig. 41. Valve lift vs. CMA, for valve driven by camshaf Rys. 41. Wznios zaworu napędzanego krzywkowo w funkcji kąta obrotu watka rozrządu

\section{Wnioski}

1. Na różnicę maksymalnych wzniosów zaworów ssących lub wydechowych napędzanych magnetoelektrycznym napędem zblokowanym ma większy wpływ różnica mas niż różnica oporów ruchu między trzonkami zaworów i ich prowadnicami. 
assemblies of the drive coil-valve may result in the same percentage difference between valve lifts. The change of the coil form does not influence the relationship.

3. As regards the blocked drive, the influence of stiffness of the coil form material and connecting element upon the lift is greater. In particular, there are differences between instantaneous displacements of the coil form and valve. However, the differences between the maximum displacements of the coil form and the valve are not big and, therefore, it is possible to control such an assembly by tracking extreme valve positions.

4. The blocked drive, configuration 2, may be used only for driving of the inlet valves due to lesser motion resistances. Driving of the exhaust valves by means of such a drive would require using high current values, which are probably not possible to generate in a vehicle system powered by the voltage of $42 \mathrm{~V}$. Moreover, it would cause overheating of the coil winding.

5. The value of stiffness of the element connecting valves and the drive should be close to the stiffness value of an analogous elements used in the analyzed blocked drives, 1 , variant 2 or 3 . The variant 2 ensures lesser weight of the valves-drive assembly.

6. The relationship between electrodynamic force and current as well as the coil displacement is non-linear. Each configuration of the drive requires conducting of a separate model analysis of such a relationship. The assumption of linear relationship between the force and current and no relationship between the force and coil displacement leads to an error of $10 \%$, particularly for high values of the current in the coil.

7. As $2 \%$ growth of weight of the integrated drive coil-valve assembly causes only $2 \%$ drop in the valve lift, it may be assumed that the drop falls within the range of $2 \%$ tolerance of lifts for correctly operating valves driven by cam drives. The wear of cams results in much greater differences between lifts of the valves driven by cam drives. Therefore it was assumed that, both for the integrated and blocked drive, the difference between weights of the coil-valves assemblies, which equals $2 \%$, does not deteriorate dynamic properties of valves as compared to the cam drive.
2. Przy napędzaniu zaworów napędem zintegrowanym, z jednakowymi wartościami siły elektromagnetycznej i oporów ruchu, różnica mas napędzanych układów cewka napędu-zawór może wywołać procentowo taką samą różnicę wzniosów zaworu. Zmiana materiału karkasu cewki nie wpływa na tę zależność.

3. W odniesieniu do napędu zblokowanego wpływ sztywności materiału karkasu i elementu łączącego na wznios zaworów jest większy. W szczególności występują różnice między chwilowymi przemieszczeniami karkasu cewki i zaworu. Jednak różnice między maksymalnymi przemieszczeniami karkasu i zaworu nie są duże i dlatego można sterować takim układem, śledząc skrajne położenia zaworu.

4. Napęd zblokowany o konfiguracji 2 może być stosowany jedynie do napędu zaworów ssących z powodu mniejszych oporów ruchu. Napędzanie takim napędem zaworów wydechowych wymagałoby użycia dużych wartości prądów, prawdopodobnie niemożliwych do wygenerowania $\mathrm{w}$ instalacji samochodu zasilanej napięciem $42 \mathrm{~V}$, a ponadto powodowałoby zbytnie grzanie się zwojów cewki.

5. Sztywność elementu łączącego zawory z napędem powinna być zbliżona do sztywności analogicznego elementu zastosowanego $\mathrm{w}$ analizowanych napędach zblokowanych o konfiguracji 1, wariant 2 lub 3. Wariant 2 zapewnia mniejszą masę układu zawory-napęd.

6. Zależność siły elektrodynamicznej od prądu oraz od przemieszczenia cewki jest nieliniowa. Każda konfiguracja napędu wymaga przeprowadzenia osobnej analizy modelowej takiej zależności. Przyjęcie liniowej zależności siły od prądu i niezależności siły od przemieszczenia cewki prowadzi do błędu rzędu 10\%, zwłaszcza przy dużych wartościach prądu w cewce.

7. Ponieważ 2-procentowy wzrost masy układu cewka napędu zintegrowanego-zawór powoduje jedynie 2-procentowy spadek wzniosu zaworu, można uznać, że mieści się to $\mathrm{w}$ zakresie $2 \%$ tolerancji wzniosów prawidłowo pracujących zaworów napędzanych krzywkowo. Zużycie krzywek powoduje, że różnice wzniosów zaworów napędzanych krzywkowo mogą być znacznie większe. Dlatego przyjęto, że zarówno w przypadku układu zintegrowanego, jak i zblokowanego różnica $2 \%$ mas układów cewka-zawór rzędu nie pogarsza właściwości dynamicznych zaworów w porównaniu z napędem krzywkowym.

\section{Nomenclature/Oznaczenia}

CA crankschaft angle/obrót wału korbowego
CMA camschaft angle/obrót wału rozrządu

RPM revolutions per minute/obroty na minute

\section{Bibliography/Literatura}

[1] blogs.Edmunds.com/straightline/2006/12/vale-camlessengine.html.

[2] www.tekstolit.com/oferta/tekstolit.htm

[3] Zbierski K.: Bezkrzywkowy magnetoelektryczny rozrząd czterosuwowego silnika spalinowego. Monografie Politechniki Łódzkiej, Wydawnictwo Politechniki Łódzkiej, Łódź 2007.

[4] www.swiatek.com.pl/regeneracja1.htm
Mr. Krzysztof Siczek, DEng. - doctor in the Mechanical Faculty at the Technical University of Lodz.

Dr inż. Krzysztof Siczek - adiunkt na Wydziale Mechanicznym Politechniki Łódzkiej.

e-mail: krzysztof.siczek@p.lodz.pl 